\title{
Morphometric Variability in a Population of the Root Vole
}

\author{
Janusz MARKOWSKI
}

Markowski J., 1980: Morphometric variability in a population of the root vole. Acta theriol., 25, 14: 155-211 [With 10 Tables \& 13 Figs.].

Examination was made of variability in body and skull dimensions in a population of the root vole Microtus oeconomus (Pallas, 1776) living in a drained sphagnum bog in the Augustów Forest (eastern Poland). Analysis was made of material consisting of 2424 individuals caught over an 9-year period (1966-1974), taking into consideration sex dimorphism, differences in seasonal generations and relation to dynamics of population numbers. The study population was subject to considerable pressure from the changing habitat (growth of tree plantations) and its numbers decreased in successive years. Sex dimorphism is particularly distinct in old adults, body and skull dimensions of males being significantly greater than those of females. Differences in these dimensions in young animals are seasonal in character. Females of the spring generation grow more rapidly and attain greater dimensions than males, whereas it is the latter which have greater body dimensions in the autumn generation. Reduction in mean values was found in successive years and in the ranges of variation in body and skull measurements observed, but this was statistically significant only in the case of body length and weight. Variations in body dimensions were not correlated with variations in the numbers of voles.

[Dep. Comp. Anat. \& Animal Ecol., Univ. of Łódź, Banacha 12/16, 90-237 (present address), and Mammals Res. Inst., Polish Acad. Sci., 17-230 Białowieża, Poland]

\section{INTRODUCTION}

In studies on variability in mammals it is possible to distinguish two classic trends in biology: the first, the purpose of which is to present the fact itself and describe variability; the second is genetic and populational in aspect, as the expression of adaptation to the habitat (S c h warz, 1969; Y a blokov, 1966; M a y r, 1974).

One of the manifestations of intrapopulation heterogeneity about which considerable information has been obtained is morphological variability. This applies both to qualitative and quantitative characteristics (see Yablokov, 1966). Analysis of morphological characteristics, as additional to their clasisical application in systematics, 
is widely used in studies on the structure and function of a species and in analysis of evolutionary transformations (F a l con e r, 1964; Schwarz, 1969; Petrusewicz, 1966; Yablokov, 1966). It must, however, be remembered that variability takes place in a wide variety of forms, each of which plays a specific role in the liffe of a population or species as a whole ( $\mathrm{S} \mathrm{c} \mathrm{h} \mathrm{w} \mathrm{a} \mathrm{r} \mathrm{z,} \mathrm{1969).}$

Studies were made of a population of the root vole Microtus oeconomus (Pallas, 1776) isolated by a habitat untypical of this species, since the animals liveid in a sphagnum bog in the Augustów Forest. Draining and other land reclamation operations carried out in 1962 in this area and the introduction of forest plantation accelerated the process of vegetation changes (Buchalczyk \& Pucek, 1968). In this way a model situation was created, enabling us to trace the course taken by a population subject to pressure of habitat conditions caused by application of cultivation operations.

In order to explain the functional significance of variability in the population of this species, the degree to which knowledge has been obtained of its ecology and biology is of great importance. In previous studies on this population $\mathrm{Buchalczy/k} \& \mathrm{Pucek}$ (1968) analysed variations in density and trapping preference; Gę bc zyńs k a (1970) estimated bioenergetic indexes and food relations, and calculated the energy) flow through a population in relation to net production of a sphagnum bog. B uchalczyk et al. (1970) estimated the damage done in forest plantations. Gę bc z yńska \& Gębczyński (1971) analysed variations in length and weight of the alimentary tract. The course taken by succession of small mammals on a drained bog has formed the subject of a separate study (Buchalczyk \& $\mathbb{P} u c e k$, 1978).

The purpose of this paper is to carry out an analysis, from many aspects, of variability in metric parameters of a population subjected to the pressure brought a'bout by specific effect of a number of factors: habitat, intrapopulation and competitive. No specialized studies aümed at determining the effects of each of the above factors on values of parameters were made during the period material was being collected, and therefore they have been treated jointly. The visible effect of their action was the constant tendency to reduction in the population numbers of the root vole in the study area (Buchalczyk \& Pucek, in prep.). The second task was to discover the range of variability in basic parameters within the age classes distinguished and to examine sex dimorphism and seasonal variability. Questions of growth rate and correlation structure of the skull will form the subjects of separate papers. 


\section{MATERIAL AND METHODS}

\subsection{Study Area}

The study area was situated in the "Biele" drained sphagnum bog situated in the Augustów Forest $\left(53^{\circ} 22^{\prime} \mathrm{N}\right.$ and $\left.23^{\circ} 22^{\prime} \mathrm{E}\right)$.

The total bog area was 34 ha and was surrounded on all sides by tall tree stands. In 1962 the bog was drained and an area of 16 ha situated in the centre was fenced in and planted with trees. In 1963 young deciduous and coniferous trees were planted in belts varying in width from 8 to $20 \mathrm{~m}$. In the majority of cases the belts were $20 \mathrm{~m}$ wide, planted with only one or a small number of species in different numerical combinations. The plantations consisted of the following species of deciduous trees: birch, alder, maple, ash, poplar, oak and osiers, and coniferous trees: pine, spruce.

As the trees grew the microclimatic conditions, shade, etc. altered, causing meadow plants to disappear and the percentage of forest species to increase. The list given by $\mathrm{G} \mathrm{eqbczy}$ ńs k (1970) of species dominating among herb layer plants reveals the wide variety of species and the transitional character of the plant associations formed.

A detailed description of the area is to be found in papers by $\mathrm{Bu}$ chalczyk \& Pucek (1968); Gębczyńska $(1969,1970)$.

\subsection{Material}

The material for the present study was made available by the Mammals Research Institute at Bialowieża and was obtained from trapping operations carried out from 1966-1794 in the »Biele" experimental area.

Animals obtained during the period from 1966 to 1967 originated from quantitative trapping based on the Standard Minimum method (SM), and a detailed analysis of the results obtained has been made by Buchalczyk \& Pucek (1968). In 1968 mammals were caught by using pitfalls placed in different cultivated areas in 5-8 lines of 20 pitfalls each, set every $10 \mathrm{~m}$ in each line. From 1969 to 1974 trapping of these mammals was carried out along 8 permanent lines, 20 pitfalls being placed every $10 \mathrm{~m}$ along the lines.

The mammals caught were measured, weighed and conserved by the standard method (Pucek, 1964). Individuals with undamaged skulls were chosen from the fixed material for further studies. When the series caught during trapping from 1966-67 were very numerous, from 50 to $75 \%$ of the total number of mammals caught in each series were chosen at random, while almost all individuals were taken from less numerous series (Table 1).

Skulls were prepared from the animals chosen, first removing the eyeballs in order to determine age. The eyeballs were placed in 10\% formalin solution (1:9). Lens were prepared from the eyeballs after a lapse of at least two weeks, then washed twice in distilled water, dried in a drier at $80^{\circ} \mathrm{C}$ for 48 hours. Both lenses were weighed together on a torsion balance with accuracy to $0.05 \mathrm{mg}$.

A total of 2424 undamaged skulls were taken for craniometric examination (Table 1), making linear measurements on them. 


\section{Table 1}

Comparison of trapping dates and effectiveness of removals of Microtus oeconomus and amount of material used for biometric analysis.

SM - removals by the Standard Minimum method.

\begin{tabular}{|c|c|c|c|c|}
\hline Trapping periods & $\begin{array}{l}\text { No. } \\
\text { trapnights }\end{array}$ & $\begin{array}{l}\text { Total } \\
\text { caught }\end{array}$ & \multicolumn{2}{|c|}{$\begin{array}{c}\text { Biometrically } \\
\text { analysed }\end{array}$} \\
\hline 1966 & & & & \\
\hline $\begin{array}{l}23.05-26.05 \text { SM1 } \\
20.07-27.07 \text { SM2 } \\
17.08-24.08\end{array}$ & $\begin{array}{l}4096 \\
8192\end{array}$ & $\begin{array}{r}324 \\
888 \\
95\end{array}$ & $\begin{array}{r}196 \\
246 \\
49\end{array}$ & $\begin{array}{l}52 \\
28 \\
52\end{array}$ \\
\hline $4.10-13.10 \begin{array}{l}\text { SM4 } \\
\text { SM3 }\end{array}$ & & $\begin{array}{c}271 \\
363\end{array}$ & 380 & 60 \\
\hline $\begin{array}{l}30.11-3.12 \\
\text { Subtotal }\end{array}$ & & $\begin{array}{r}107 \\
2048\end{array}$ & $\begin{array}{r}97 \\
941\end{array}$ & $\begin{array}{l}91 \\
46\end{array}$ \\
\hline $\begin{array}{l}1967 \\
6.05-12.05 \\
27.06-1.07 \text { SM5 } \\
23.09 \_28.09 \text { SM6 } \\
\text { Subtotal }\end{array}$ & $\begin{array}{l}3840 \\
4608\end{array}$ & $\begin{array}{r}159 \\
570 \\
393 \\
1122\end{array}$ & $\begin{array}{l}133 \\
259 \\
135 \\
527\end{array}$ & $\begin{array}{l}84 \\
45 \\
34 \\
47\end{array}$ \\
\hline $\begin{array}{c}1968 \\
8.05-12.05 \\
18.07-3.08 \\
5.10-12.10 \text { SiM7 } \\
\text { Subtotal }\end{array}$ & $\begin{array}{r}550 \\
2720 \\
6144\end{array}$ & $\begin{array}{l}142 \\
163 \\
246 \\
551\end{array}$ & $\begin{array}{r}134 \\
133 \\
94 \\
361\end{array}$ & $\begin{array}{l}94 \\
81 \\
38 \\
65\end{array}$ \\
\hline $\begin{array}{c}1969 \\
10.06-14.06 \\
15.07-19.07 \\
3.09-8.09 \\
11.11-15.11 \\
\text { Subtotal }\end{array}$ & $\begin{array}{l}800 \\
800 \\
9.60 \\
800\end{array}$ & $\begin{array}{r}72 \\
88 \\
64 \\
55 \\
279\end{array}$ & $\begin{array}{r}57 \\
78 \\
57 \\
44 \\
236\end{array}$ & $\begin{array}{l}79 \\
88 \\
89 \\
80 \\
85\end{array}$ \\
\hline $\begin{array}{c}1970 \\
5.05-8.05 \\
18.07-23.07 \\
29.09-3.10\end{array}$ & $\begin{array}{l}640 \\
960 \\
800\end{array}$ & $\begin{array}{r}30 \\
141 \\
91\end{array}$ & $\begin{array}{r}27 \\
120 \\
79\end{array}$ & $\begin{array}{l}90 \\
85 \\
87\end{array}$ \\
\hline $\begin{array}{l}\quad 1971-74 \\
\text { Spring } \\
\text { Summer } \\
\text { Autumn } \\
\quad \text { Subtotal }\end{array}$ & & $\begin{array}{r}43 \\
57 \\
54 \\
154\end{array}$ & $\begin{array}{r}38 \\
52 \\
44 \\
134\end{array}$ & $\begin{array}{l}88 \\
91 \\
81 \\
87\end{array}$ \\
\hline Total & & 4416 & 2424 & 55 \\
\hline
\end{tabular}

\subsection{Characteristics of Age Classes}

The method of determining the age of voles on the basis of dry lens weight is widely considered as the most convenient. Martinet (1966) found a high degree of correlation between age and dry lens weight for Microtus arvalis, as did Gorley \& Jannett (1975) for Microtus montanus and $M$. pinetorum. A s kaner \& Hans on (1967) considered it as more reliable than measurement of the prismatic parts of $M_{1}$ for the genus Clethrionomys. This method gives good results, but makes strictly standardized conditions for conserving and preparing lens essential (Morris, 1972; Pucek \& Low e, 1975). 
It proved possible to take the dry lens weight as one of criteria for determining age since: the joint 24-hour period of preliminary conservation of all animals in $4 \%$ formol solution quickly penetrates and fixes animal tissues well; in the second place all the lenses were prepared again the standard way. During the final preparation process a few lenses flaked and these were eliminated from the study.

The dry lens weight itself could not form the only index in the present study for two reasons: the dry lens weight was known for about $85 \%$ of the individuals, and in the second place no model was available to enable increase in lens weight to be related to age. On this account, by means of indirect analysis of part of the material, it proved possible to determine age classes and ranges of lens weight simultaneously, taking trapping dates into consideration. For this purpose correlation diagrams were drawn up between condylobasal length and dry lens weight for different trapping times in 1966 and 1967. This made it possible to divide the material into 5 groups and to trace their duration in the population. Thus having at our disposal data on length of the reproduction period and duration of gestation (Gębczyńska \& B uchalczyk, 1969; Pucek, in prep.), and skulls of individuals kept in captivity, it proved possible to establish the relative age of the age classes distinguished.

Age class I - juvenis. This included animals with lens weight up to $2 \mathrm{mg}$ (exceptionally to $2.15 \mathrm{mg}$ ) and $\mathrm{Cb}$ length up to $21.5 \mathrm{~mm}$ (exceptionally large individuals of up to $22.5 \mathrm{~mm}$ were occasionally found). The skull is rounded, without thickenings, with a strongly convex outline, the rostral part short, the zygomatic arch at most slightly broader than braincase breadth. The clearly visible suture between the basilar part of the occipital and the lateral part and the frontal suture is visible along $2 / 3$ of its length. $M_{3}$ in the maxilla and mandible are not fully grown and the enamel loop was not closed on the remaining molars. Relative age up to one month.

Age class II - subadultus. Animals with lens weight from 2.10 (sporadically from 1.80 ) to $3.10 \mathrm{mg}, \mathrm{Cb}$ length $21.5-24 \mathrm{~mm}$ (exceptionally to $24.3 \mathrm{~mm}$ ). Bone laminae appear on the frontal bones which form a small ring on the interorbital crest with a wide and shallow sulcus in the interorbital part. Relative age from one month to six weeks.

Age class III - adultus $I$. This class included animals with lens weight from 3.10 to $3.80 \mathrm{mg}$ and in the late autumn individuals with lens weight of up to $4.40 \mathrm{mg}$, with $\mathrm{Cb}$ length $24.0-26.0 \mathrm{~mm}$. The skulls have clearly formed bone laminae on the frontal bones. The bony ridges of the interorbital crest approach each other. The bony crest between the mastoid bone and the squamous part of the temporal bone is well formed. The occipitosphenoid suture can still be seen at the base of the skull. Reiative age from six weeks to three months.

Age class IV - adultus II. Animals with lens weight of 3.90 to $5.00 \mathrm{mg}, \mathrm{Cb}$ length 26-27.5 mm (exceptionally to $27.9 \mathrm{~mm}$ ) were allocated to this class. The skull has well formed laminae and bony crest. The crest of the mastoid bone connects with the crest on the lambdoid suture, forming an uninterrupted nuchal crest. The occipito-sphenoid suture disappears. Relative age from four to seven months.

Age class V - senex. This class is formed almost exclusively by individuals caught in the second calendar year and sporadically by individuals in the first year of life caught in the late autumn (October, November). The lens weight of individuals in this class varied from 4.60 to $7.90 \mathrm{mg}, \mathrm{Cb}$ length $26-30.0 \mathrm{~mm}$. 
The skull has a straight profile with strongly developed zygomatic arches and rostral part. The interorbital crest is clearly formed throughout its length. Relative age over seven months.

In earlier studies of $M$. oeconomus the first age class included individuals of up to even three and a half months (Kratochvil \& R os i cky, 1955; W asilewski, 1956b), and consequently this class is widely varied and includes both »nest" and sexually mature individuals. Data on growth rate (S c h w a r z et al., 1964; Ka ras e e a et al., 1957) show that the most rapid growth changes in the body and skull take place during $3-4$ months for the spring generation and 1-2 months for the autumn generation. If a wide range of age is accepted for age class I the actual growth changes are effaced.

Intensive removals by means of the Standard Minimum method resulted in relatively large numbers of »nest « individuals being caught, and consequently it proved possible to describe this age group biometrically and to obtain fuller data for analysis of changes in different dimensions during postnatal development. The division into five age classes used in this study is thus an enlargement of the youngest age class.

\subsection{Comparison of Measurements and Indexes}

Five basic measurements were made on the mammals caubht: head and body, tail, hind foot, ear length and body weight determined with accuracy to $0.1 \mathrm{~g}$. In addition the dry lens weight was also available.

Ten linear measurements were made on the skulls (Fig. 1), making use of the studies by Wasilewski (195b), Pucek (1964) and Ruprecht (1974) when choosing which measurements to make. Measurements were made with a nonius slide rule with scale up to $0.1 \mathrm{~mm}$ in the sagittal plane.

Measurements are given below; abbreviations are used throughout in the text:

1. Condylobasal length $(\mathrm{CbL})$

2. Brain-case length (after Guld \& Kreeger, 1948) (BcL)

3. Diastema length $(D L)$

4. Maxillary tooth-row length $(M x T R L)$

5. Mandibular length $(M d L)$

6. Brain-case breadth $(B C B)$

7. Zygomatic breadth $(Z y B)$

8. Interorbital constriction (IC)

9. Rostrum breadth (RB)

10. Brain-case height between bullae $(\mathrm{BCH})$

Or the basis of the values obtained for skull measurements calculation was made of 7 quotient indexes:

1. (Brain-case length $\times 100): \mathrm{Cb}$ length

2. (Diastema length $\times 100)$ : Cb length

3. (Brain-case breadth $\times 100$ ): $\mathrm{Cb}$ length

4. (Zygomatic breadth $\times 100)$ : $\mathrm{Cb}$ length

5. (Interorbital constriction $\times 100)$ : $\mathrm{Cb}$ length

6. (Brain-case height $\times 100): \mathrm{Cb}$ length

7. (Double height of brain-case): (Cb length + brain-case breadth) - (After Hrdlička-Kočka, from P u c e k, 1968) 

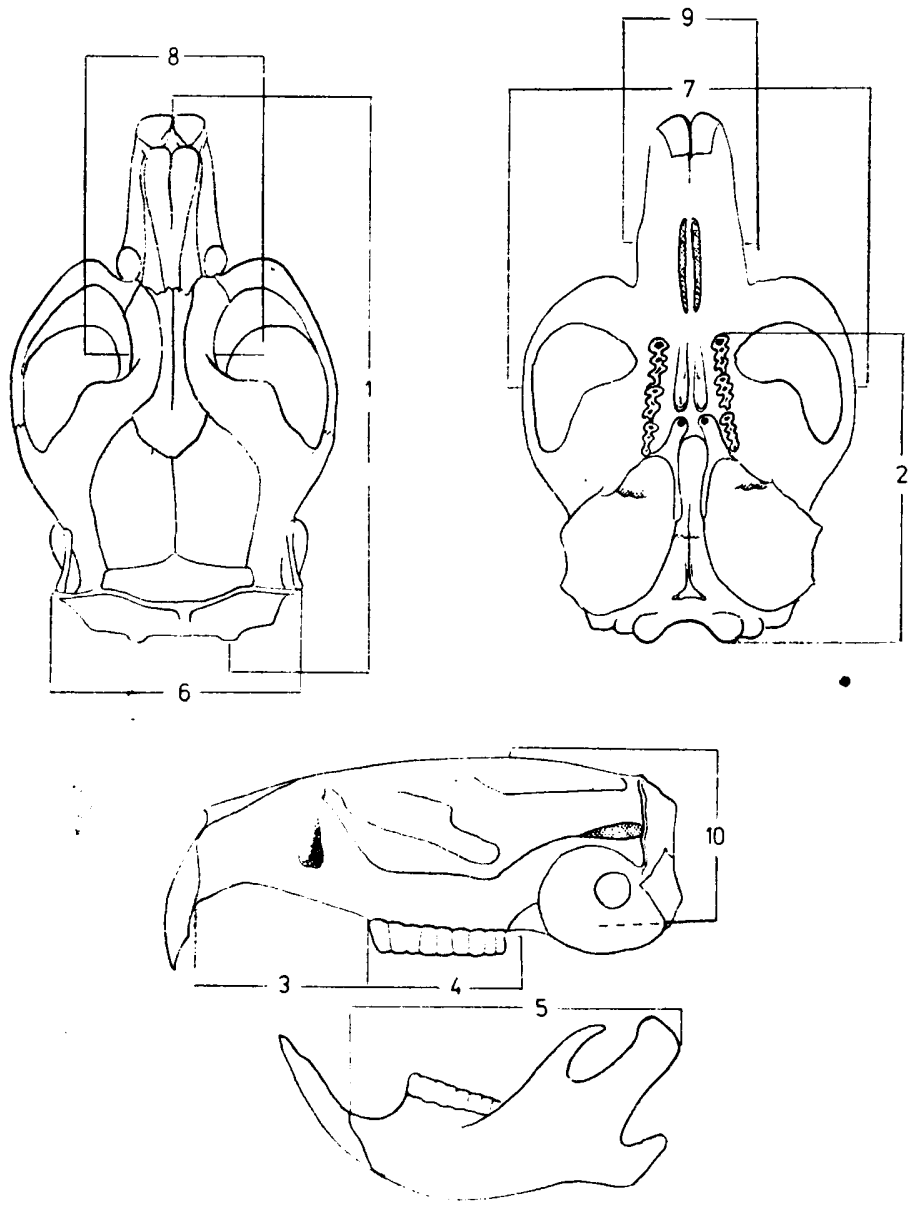

Fig. 1. Details of skull measurements in the root vole.

1 - Cb length $(C b L), 2$ - Brain-case length $(B c L), 3$ - Diastema length (DL), 4 - Maxillary tooth-row length (MxTRL), 5 - Mandibular length (MdL), 6 Brain-case breadth $(B C B), 7$ - Zygomatic breadth $(\mathrm{ZyB}), 8$ - Interorbital constriction (IC), 9 - Rostrum breadth (RB), 10 - Brain-case height (BcH)

\subsection{Procedure for Processing Data}

In order to describe the different samples in age classes and trapping periods for different body and skull measurements, ranges of variability were given (min. - max.) and the basic statistical parameters calculated: mean (X), standard deviation (SD) and coefficient of variation (CV). The material from 1971-1974 was combined for statistical calculations on account of the small numbers in samples.

In order to define variability in the study population analysis was made of percentage distributions of body weight (for males only), body length, dry lens weight and condylobasal length, diastema length, brain-case breadth, brain-case height in different trapping seasons and successive study years for the groups 
distinguished. It is more convenient to replace single-peak distribution diagrams by figures defining the curve asymmetry and grouping of values of the variable round the arithmetical mean. For this purpose it was necessary to use central moments of value distributions expressed in units of standard deviation: third, the so-called relative skewness measure (S), fourth, so-called kurtosis (K) (Krzysztofiak \& Urbanek, 1975).

$$
A=\frac{\mu_{3}}{\sqrt{\mu_{2}^{3}}} \quad K=\frac{\mu_{4}}{\mu_{2}^{2}}
$$

where: $\mu_{2}, 3,4=$ successive moments of distributions.

$$
\mu_{k}=\frac{\sum(x-\bar{x})^{k}}{n}
$$

In order to give a fuller description of distributions, positional means were also given: median (Me), mode (Mo). In addition examination was made of variations in mean values of some body and skull parameters of individuals born in the given year and for old adults. Significance of differences between the means for different dimensions were checked by the $t$-Student test, taking only one significance level $P=0.05$. When analysing dimorphic differences, use was made of the variance analysis and significance of differences was checked with two significance levels $P=0.05$ and $P=0.01$.

In order to see whether variations in body dimensions are cyclic in character use was made of the method proposed by $\mathrm{Krebs}$ (1964b). Calculation was made of the coefficient for regression equation between two parameters: body length $(L)$ and $\mathrm{Cb}$. length, and then mean deviation from the line of regression was calculated for young individuals and old adults in three growing seasons in successive years by means of the equation:

$$
\begin{aligned}
& Y=\bar{y}+b\left(X_{\circ}-\bar{x}\right) \\
& D=Y_{\mathrm{o}}-Y
\end{aligned}
$$

where:

$D$ - deviation from regression

$Y$ - anticipated value of deviation $Y$

$Y_{0}$ - observed value $Y$ for $(a, b \ldots n)$

$X_{0}$ - observed value $X$ for $(a, b \ldots n)$

$\bar{y}, \bar{x}$ - means

$b$ - angle coefficient of straigthline regression

All calculations were made in the Computer Centre of the Institute of Mathematics of Eódź University on an Odra 1305 computer.

\section{RESULTS}

\subsection{Sex Dimorphism in Body and Skull Measurements}

Sex dimonphism is manifested more clearly as the animals arge. Generally speaking males are larger than females. In the first age class 
differences between means are not statistically significant. In further age classes the number of statistically significant differences in measurements gradually increases from 9 in class II to 16 (out of 23 analyzeid) in class $\mathrm{V}$ (Table 2); males attaining greaiter dimensions in classes III and V, and females in class IV.

Two of the linear parameters: hind foot and interorbital constriction during postnatal development (from age class II to V) are greater in

Table 2

Comparisun of statistically significant differences between females and males in the age classes distinguished

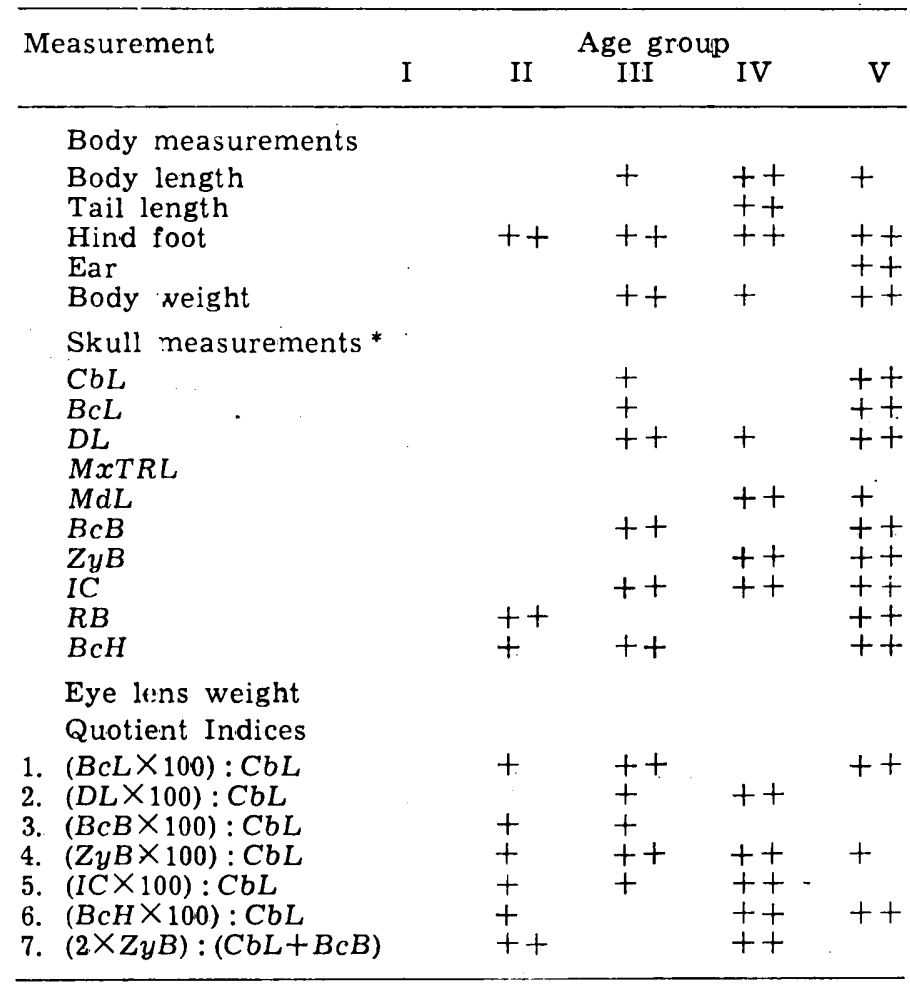

+ Differences statistically significant at $p=0.05$

++ Difference statistically significant at $p=0.01$

* For explanation of symbols see page 160

male:s and highly statistically significant $(P<0.01)$ (Table 2$)$. On the other hand, with increasing age the number of significant differences in mean values of skull indexes decreases from 6 in age class II to 2 in class $\mathrm{V}$. 
Table 3

Percentage increased in body and skull dimensions and in cranial indexes in $M$. oeconomus in different age classes, for males (M) and females (F)

Mean values for age class I were taken as $100 \%$.

\begin{tabular}{|c|c|c|c|c|c|}
\hline Measurement & & II & III & IV & $\mathrm{V}$ \\
\hline \multicolumn{6}{|c|}{ Body measurements } \\
\hline Body length & $\underset{\mathrm{F}}{\mathrm{M}}$ & $\begin{array}{l}18.0 \\
16.9\end{array}$ & $\begin{array}{l}30.5 \\
31.8\end{array}$ & $\begin{array}{l}45.8 \\
51.4\end{array}$ & $\begin{array}{l}59.6 \\
56.5\end{array}$ \\
\hline \multirow[t]{2}{*}{ Tail length } & $\mathbf{M}$ & 18.6 & 30.7 & 51.9 & 61.3 \\
\hline & $\begin{array}{c}\mathrm{F} \\
\mathrm{M}\end{array}$ & $\begin{array}{r}20.9 \\
8.9\end{array}$ & $\begin{array}{l}34.9 \\
11.9\end{array}$ & $\begin{array}{l}62.9 \\
14.6\end{array}$ & $\begin{array}{l}66.8 \\
11.6\end{array}$ \\
\hline Hind foot & $\mathrm{F}$ & 6.5 & 10.6 & 12.5 & 9.8 \\
\hline \multirow[t]{2}{*}{ Ear } & $\mathbf{M}$ & 20.2 & 27.8 & 35.5 & 42.9 \\
\hline & $F$ & 20.9 & 28.8 & 38.3 & 39.8 \\
\hline \multirow[t]{2}{*}{ Body weight } & $\mathbf{M}$ & 55.3 & 92.6 & 200.0 & 296.4 \\
\hline & $F$ & 57.5 & 103.1 & 226.4 & 261.3 \\
\hline \multicolumn{6}{|c|}{ Skull measurements } \\
\hline \multirow[t]{2}{*}{$\mathrm{CbL}$} & $\mathbf{M}$ & 10.5 & 20.5 & 29.2 & 35.1 \\
\hline & $F$ & 11.2 & 20.4 & 29.9 & 32.3 \\
\hline \multirow[t]{2}{*}{$B c L$} & $\mathbf{M}$ & 9.7 & 19.3 & 25.8 & 31.3 \\
\hline & $\mathrm{F}$ & 10.2 & 18.6 & 26.5 & 28.6 \\
\hline \multirow[t]{2}{*}{$D L$} & $\mathbf{M}$ & 11.7 & 23.3 & 33.1 & 40.7 \\
\hline & $\mathrm{F}$ & 12.6 & 22.9 & 35.0 & 38.4 \\
\hline \multirow[t]{2}{*}{$M x T R L$} & $\mathbf{M}$ & 7.7 & 13,1 & 16.7 & 19.3 \\
\hline & $F$ & 7.5 & 12.8 & 17.1 & 19.3 \\
\hline \multirow[t]{2}{*}{$M d L$} & $\mathbf{M}$ & 7.4 & 14.4 & 20.0 & 25.2 \\
\hline & $\mathrm{F}$ & 7.9 & 15.1 & 22.1 & 25.2 \\
\hline \multirow[t]{2}{*}{$B c B$} & $\mathrm{M}$ & 7.0 & 13.4 & 18.0 & 21.7 \\
\hline & $\mathrm{F}$ & 6.9 & 12.8 & 18.4 & 21.5 \\
\hline \multirow[t]{2}{*}{$Z y B$} & $\mathrm{M}$ & 7.9 & 15.3 & 24.5 & 33.3 \\
\hline & $\mathrm{F}$ & 7.6 & 15.4 & 26.5 & 30.5 \\
\hline \multirow[t]{2}{*}{ IC } & $\mathbf{M}$ & 2.4 & 5.0 & 6.5 & 6.2 \\
\hline & $F$ & 3.0 & 4.8 & 6.0 & 4.5 \\
\hline \multirow[t]{2}{*}{$R B$} & $\mathbf{M}$ & 5.3 & 9.5 & 18.4 & 24.8 \\
\hline & $F$ & 4.1 & 9.2 & 17.7 & 18.9 \\
\hline \multirow[t]{2}{*}{$\mathrm{BcH}$} & M & 2.9 & 4.0 & 6.7 & 10.1 \\
\hline & $F$ & 2.7 & 3.8 & 6.7 & 7.7 \\
\hline \multirow[t]{2}{*}{ Eye lens weight } & $\mathrm{M}$ & 45.7 & 125.0 & 161.0 & 238.4 \\
\hline & $F$ & 52.9 & 134.2 & 172.2 & 261.3 \\
\hline \multicolumn{2}{|l|}{ Quotient Indices } & & & & 1 \\
\hline \multirow[t]{2}{*}{ 1. $(B c L \times 100): C b L$} & M & -1.1 & -2.1 & -2.7 & -3.4 \\
\hline & $\mathrm{F}$ & -0.9 & -1.5 & -2.3 & -3.0 \\
\hline \multirow[t]{2}{*}{ 2. $(D L \times 100): C b L$} & M & 1.2 & 2.3 & 3.1 & 4.2 \\
\hline & $\mathrm{F}$ & 1.0 & 1.8 & 3.7 & 4.3 \\
\hline \multirow[t]{2}{*}{ 3. $(B c B \times 100): C b L$} & $\mathrm{M}$ & -3.2 & -6.0 & -8.4 & -10.0 \\
\hline & $\mathrm{F}$ & -4.0 & -6.5 & -8.4 & -9.9 \\
\hline 4. $(Z y B \times 100): C b L$ & $M$ & -2.4 & -4.3 & -3.4 & -1.5 \\
\hline & $\mathrm{F}$ & -3.3 & -4.3 & -2.7 & -1.4 \\
\hline 5. $(I C \times 100): C b L$ & $\mathbf{M}$ & -7.4 & -12.8 & -17.3 & -21.5 \\
\hline & $\mathrm{F}$ & -7.7 & -13.1 & -18.6 & -21.1 \\
\hline 6. $(B c H \times 100): C b L$ & $M$ & -7.3 & -13.8 & -17.3 & -118.6 \\
\hline & $F$ & -7.9 & -13.9 & -18.0 & -19.0 \\
\hline 7. $(2 \times Z y B):$ & $\mathrm{M}$ & -6.3 & -12.8 & -14.9 & -17.0 \\
\hline$(C b L+B c B)$ & $F$ & -6.6 & -12.8 & -17.0 & -17.0 \\
\hline
\end{tabular}



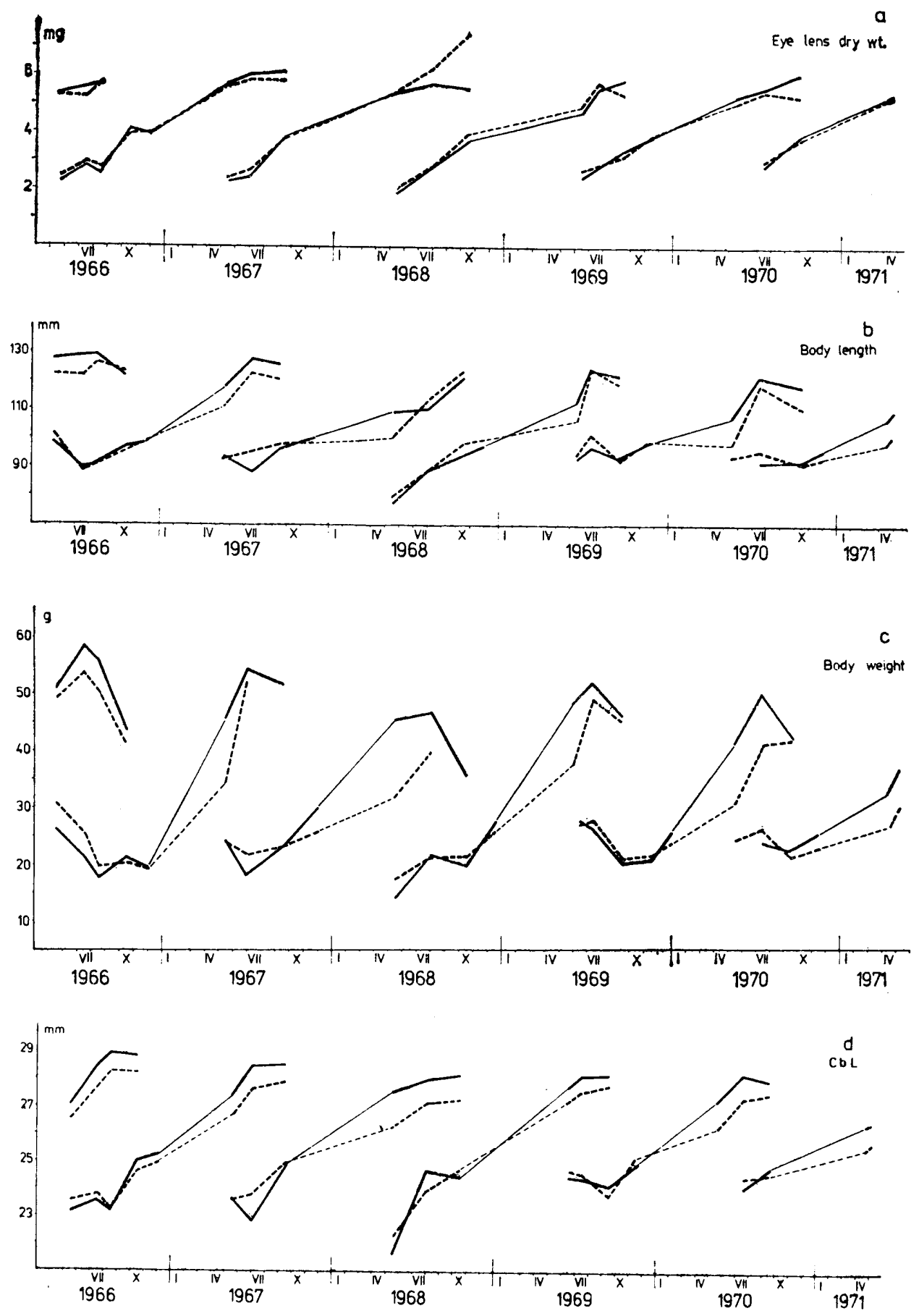

Fig. 2. Concluded on page 166. 

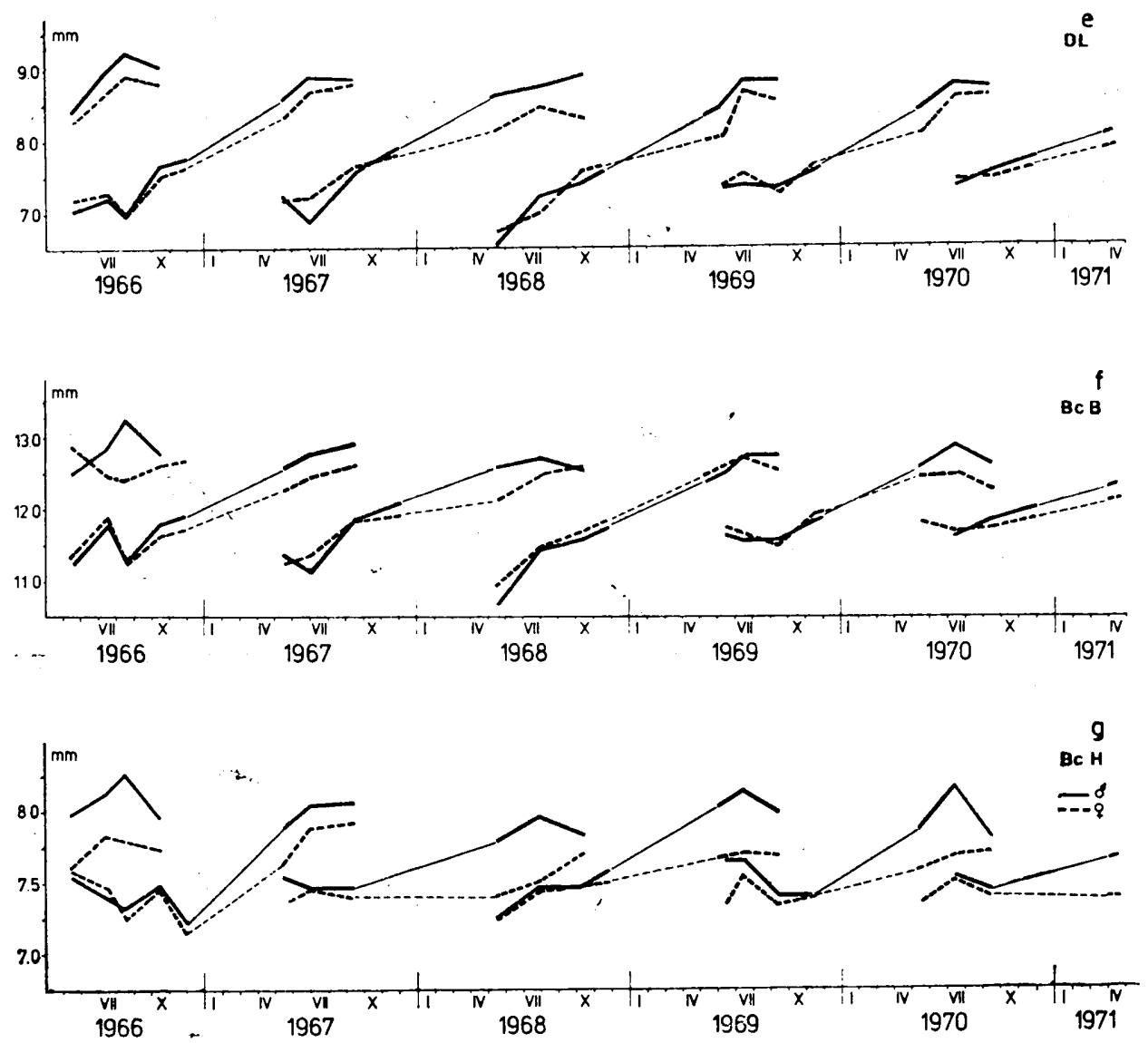

Fig. 2. Variations in some body and skull measurements of the root vole in different generations.

a - Eye lens dry wt., b - Body length, c - Body weight, $d-C b L$, e - $D L$, $\mathrm{f}-\mathrm{BcB}, \mathrm{g}-\mathrm{BcH}$. Basis for charting diagrams was the arithmetical mean for males and females in successive removals. Solid line - males, broken line females.

Sex dimorphism is also evident in the different growth rate of body and skull measurements. With the exception of age class IV, almost all dimensions in males are distinguished by greater increases (Table 3)

When analyzing mean values of different body and skull dimensions in corresponding age classes and growing seasons it can be seen that at first young males (class I and II) grow slightly more rapidly than females. In age class III mean values are sometimes greater in males and sometimes in females. In summer, when only young females attain sexual maturity, the mean values of their dimensions are usually higher than in males. Statistically significant differences relate to: body length, body weight $(P<0.05)$. Mean values for skull measurements are also 

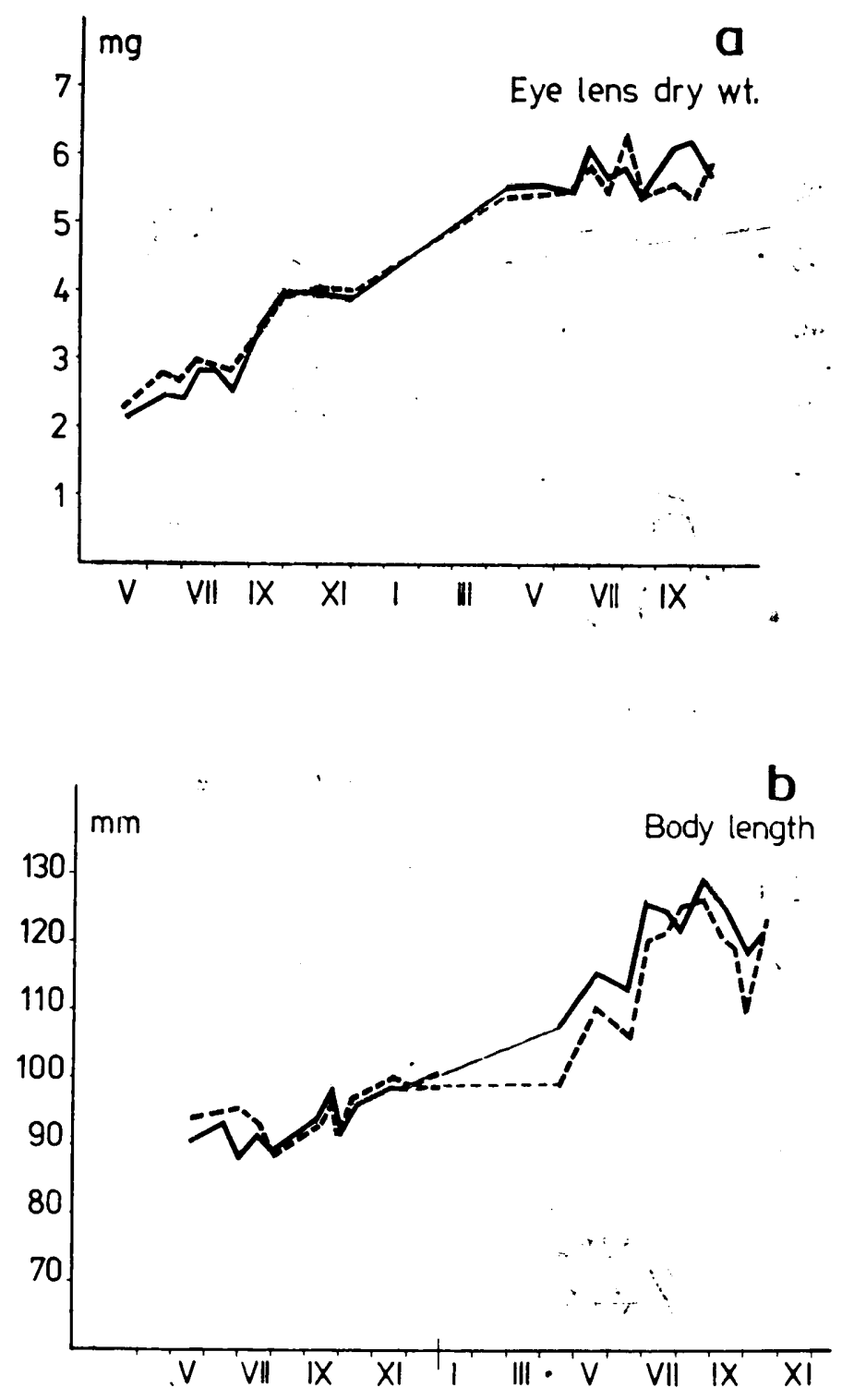

Fig. 3. Concluded on page 170.

higher, although these were not statictically significant differences. The relation between growth rate and attainment of sexual maturity is confirmed in old adults also. Males mature sexually earlier and are 

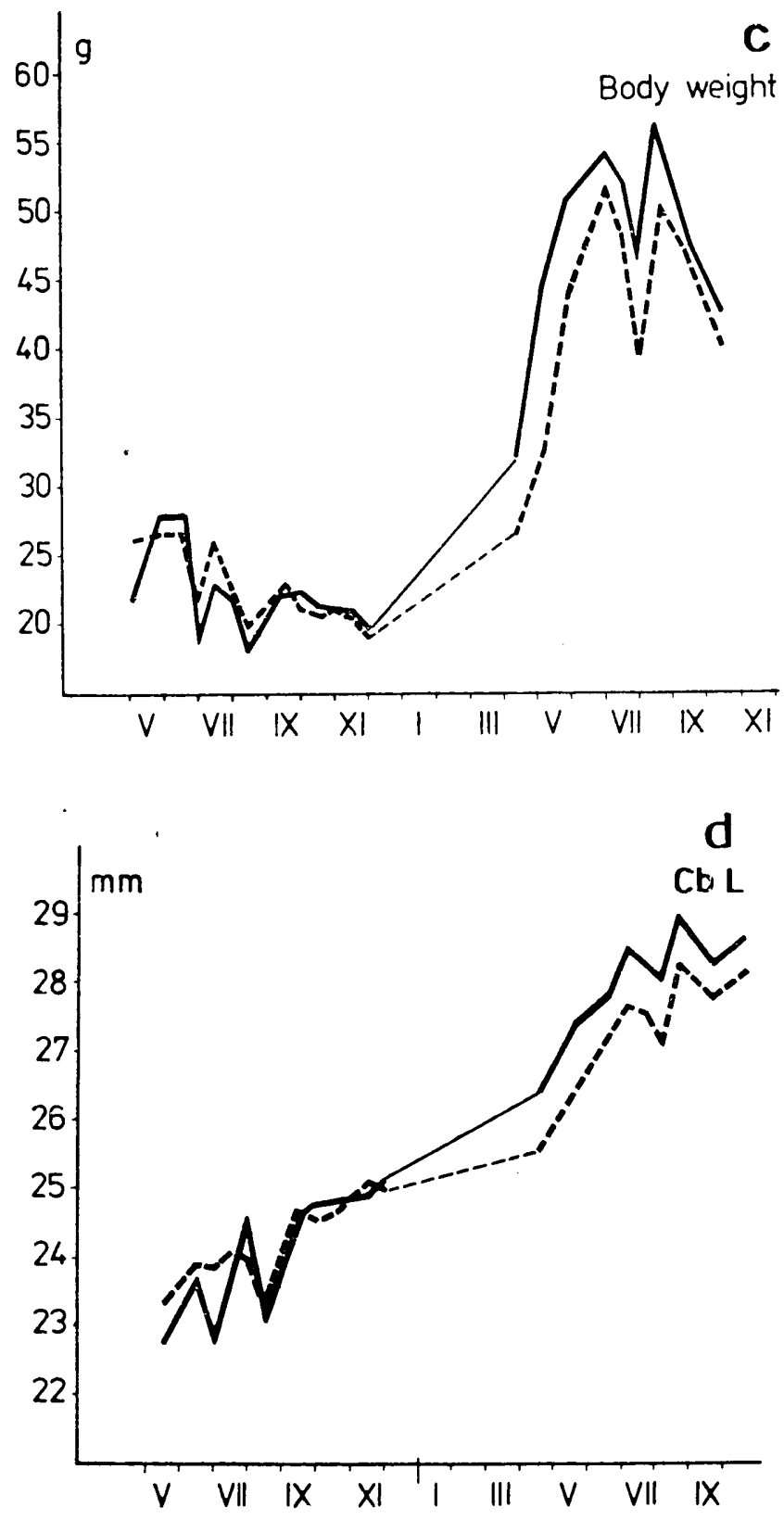

Fig. 3. Concluded on page 170. 

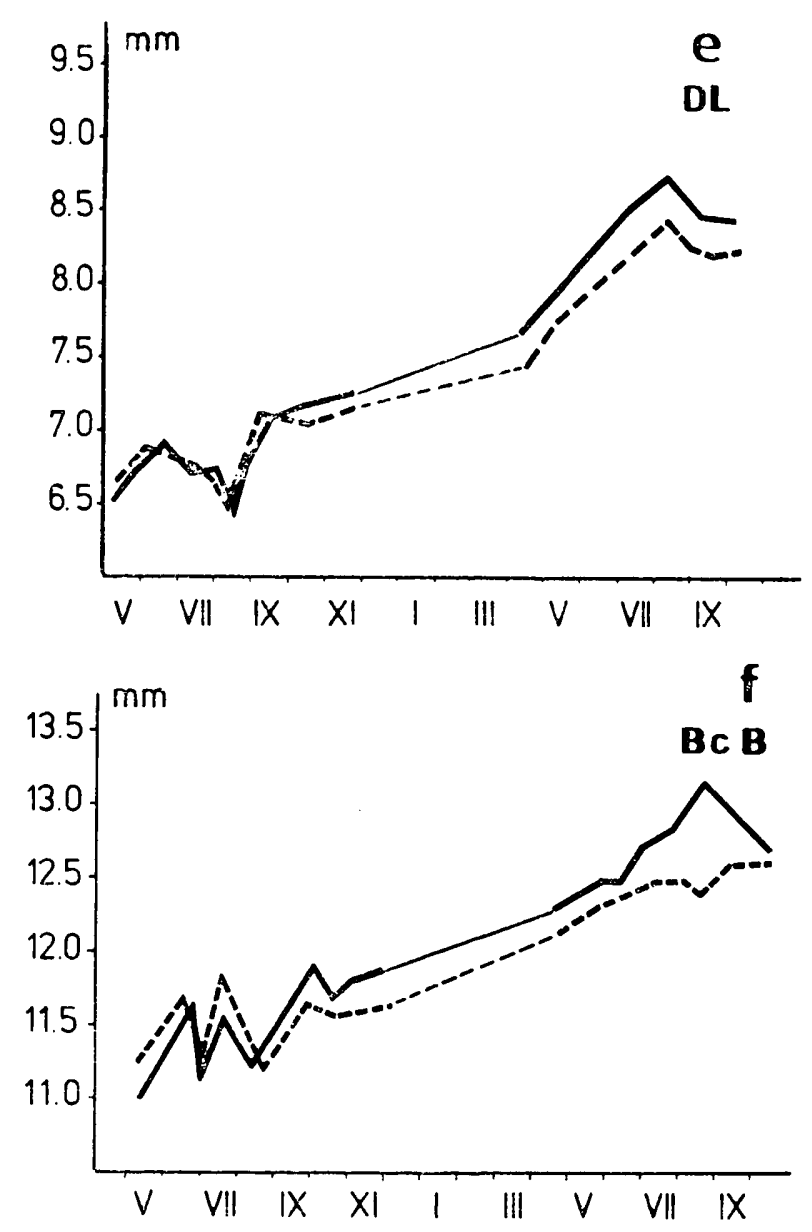

Fig. 3. Concluded on page 170 .

characiterized by greater increases in body and skull measurements in spring. The dimensions of females do not become similar to those of males until two months later (Fig. 2,3).

In the study population old adult males are always larger than females, the greatest differences being manifested in spring, but decreasing during summer. It would therefore appear that depending on the quality of the samples at the disposal of different authors, in some cases sex dimorphism was shown to exist (D e h n e l, 1946; Ehik, 1953; B a uer, 1953) and others not (Wasilewski, 1956b; $\mathrm{K}$ a n e p, 1967). The results obtained in this study indicated that individuals of the two sexes should be analyzed separately. 


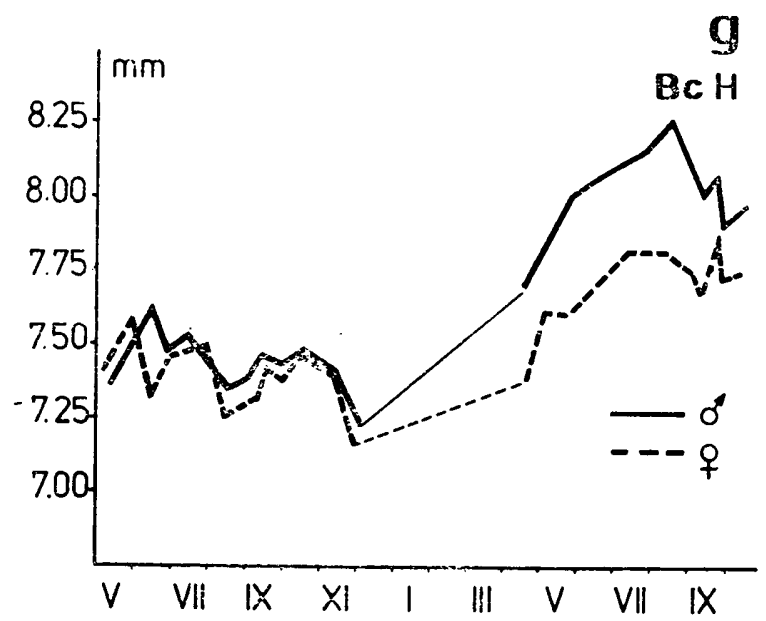

Fig. 3. Variations in some body and skull measurements of the root vole in two generations.

Basis for charting diagrams was formed by arithmetical means calculated for each month on basis of data for period 1966-1974. Symbols as for. Fig. 2.

\subsection{Intrapopulation Differentiation}

\subsubsection{Dry Lens Weight}

There are two distinct peaks in the distribution of weight of dry lens mass. The first peak is different in the two sexes, occurring at $3.0 \mathrm{mg}$ for females and $2.5 \mathrm{mg}$ for males, while the second peak for the two - sexes occurs at the same value - $4.5 \mathrm{mg}$ (Fig. 4).

This second peak is due to the fact that in this interval the upper limit of lens size is attained by the current year's individuals and also

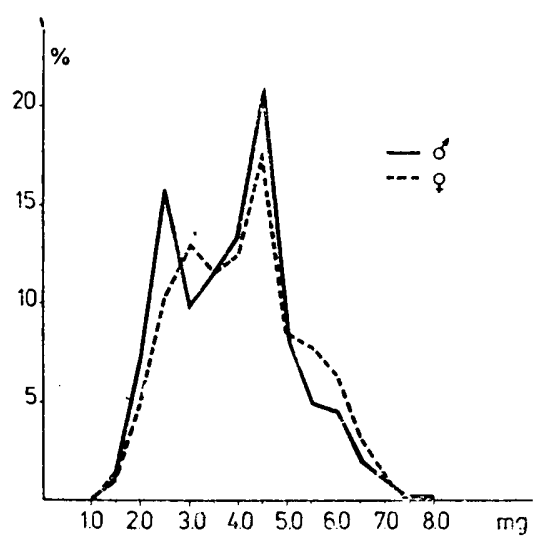

Fig. 4. Distribution of frequencies of dry eye lens weight in males and females. 
the beginning of the range of lens weight of old adult individuals. Common classes of 4.0-4.6 mg, however, in which individuals of one or the other group could be observed, never occur together in the given sample (Table 4).

Table 4

Distribution of numbers of $M$. oeconomus individuals according to dry eye lens weight (in $\mathrm{mg}$ ), taking into consideration age and trapping season in 1966

\begin{tabular}{|c|c|c|c|c|c|c|c|c|c|c|c|c|c|c|}
\hline Time of catch & $\begin{array}{l}\text { Age } \\
\text { groups }\end{array}$ & \begin{tabular}{l}
8 \\
0 \\
\hdashline \\
1 \\
0 \\
0 \\
0 \\
-1
\end{tabular} & 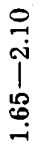 & 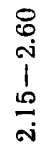 & 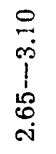 & 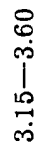 & 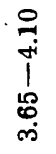 & 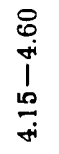 & $\begin{array}{l}0 \\
0 \\
10 \\
10 \\
0 \\
0 \\
0 \\
0\end{array}$ & $\begin{array}{l}\stackrel{8}{0} \\
\dot{0} \\
\stackrel{0}{0} \\
\stackrel{0}{0}\end{array}$ & $\begin{array}{l}0 \\
\stackrel{0}{0} \\
\stackrel{0}{0} \\
\stackrel{0}{0} \\
0\end{array}$ & $\begin{array}{l}8 \\
8 \\
0 \\
1 \\
1 \\
0 \\
0\end{array}$ & $\begin{array}{l}0 \\
\stackrel{1}{0} \\
1 \\
1 \\
0 \\
0 \\
0\end{array}$ & 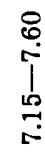 \\
\hline 23-26 May & $\begin{array}{l}\text { I } \\
\text { II } \\
\text { III } \\
\text { IV } \\
\text { V }\end{array}$ & 4 & $\begin{array}{r}11 \\
1\end{array}$ & $\begin{array}{r}5 \\
20\end{array}$ & $\begin{array}{r}6 \\
31\end{array}$ & 5 & 1 & 4 & 8 & 25 & 36 & 10 & 1 & 1 \\
\hline $20-27$ July & $\begin{array}{l}\text { I } \\
\text { II } \\
\text { III } \\
\text { IV } \\
\text { V }\end{array}$ & 1 & 3 & $\begin{array}{l}1 \\
1\end{array}$ & 12 & $\begin{array}{l}8 \\
7\end{array}$ & 18 & $\begin{array}{l}4 \\
2\end{array}$ & $\begin{array}{l}2 \\
2\end{array}$ & 3 & 1 & 1 & 1 & 1 \\
\hline 17-24.August & $\begin{array}{l}\text { I } \\
\text { II } \\
\text { III } \\
\text { IV } \\
\text { V }\end{array}$ & 6 & 4 & 7 & $\begin{array}{l}4 \\
4\end{array}$ & 3 & 3 & 2 & 4 & 2 & 1 & & & \\
\hline 4-13 October & $\begin{array}{l}\text { I } \\
\text { II } \\
\text { III } \\
\text { IV } \\
\text { V }\end{array}$ & 1 & 2 & 1 & 9 & $\begin{array}{l}3 \\
6\end{array}$ & 13 & $\begin{array}{r}46 \\
5\end{array}$ & $\begin{array}{r}17 \\
1\end{array}$ & $\begin{array}{r}8 \\
19\end{array}$ & 10 & 11 & 5 & \\
\hline $\begin{aligned} & 30 \text { November } \\
& 3 \text { December }\end{aligned}$ & III & & & & & 17 & 24 & 34 & $\begin{array}{c}5 \\
12\end{array}$ & 5 & 1 & & & \\
\hline
\end{tabular}

When comparison is made of the mean values for lens weighit in different trapping series for young individuals born in the current year and old individuals born the preceding year, this divides the material into two distinct generations, the curve of increase in lens weight in the population taking an S-shape. On account of the 3-4 removal operations made during the course of the year this shape of curv'e is not evident (Fig. 2a). A fuller picture of increase in lens weight was obtained from analysis of means from different months for the whole study period (Fig. 3a).

During voles' lifetime, usually lasting 18 months at most under natural conditions (W a s i le w s k i, 1956b), lens weight increases from 
0.7 to $7.9 \mathrm{mg}$, which gives $0.4 \mathrm{mg}$ increase per month, whereas the mean increase in lens weight calculated from mean values of weight fluctuations (Fig. 3a) in the population is $0.28 \mathrm{mg}$ per month.

\subsubsection{Body Length}

The distributions of variation in body length in the study population are almost symmetrical, with a single peak for both sexes. Sex dimorphism is only very slightly manifested. Higher frequency in the range from $110-130 \mathrm{~mm}$ was found for females, but this may be due to the overestimated measurements in gestating individuals. In males higher frequencies were found in the ranges from $90-110$ and $130-140$ $\mathrm{mm}$. The range of this measurement is identical for the two sexes.

Distinct dimorphic differences in body length are manifested in spring (e.g. in April removals), when the ranges of body length coincide only to a slight degree and males are distinctly larger. Differences even up with the passage of time and differ only slightly during summer (Fig. 3b). Large individuals over $95 \mathrm{~mm}$ predominate in the population during the early spring period, but as from May the percentage of smaller individuals increases. The gradual entry of new individuals causes considerable asymmetry of distributions of this dimension in the population, and usually they are negative asymmetry distributions. An example of this is the distribution for May 1966 for females (Fig. 5b). There is also a distribution with positive asymmetry, e.g. the sample from May 1966 for males, due to the small numbers of adult animals (Fig. 5a).

In summer trappings as from the end of June and beginning of July up to August, distributions of body length are curves with two- or three peaks, this being particularly clear in the case of females (Figs. $5 \mathrm{a}, \mathrm{b})$. Decline of curves at values of $110 \mathrm{~mm}$ in both sexes is due to the fact that this is the extreme size value for young animals born the current year and the beginning of the range for old individuals.

In autumn distributions have two peaks, the second of which is very slight. Immediately before the winter period - end of November and beginning of December 1966 - the distribution is symmetrical with one peak for males (Fig. 5a), while a small number of individuals over $110 \mathrm{~mm}$ are still found among femalés (Fig. 5b).

In summer (June-July) the peak of the body length distribution for young individuals occurs at the value $90 \mathrm{~mm}$, and in August at $100 \mathrm{~mm}$, which with the continuous entry of individuals into the population points to the high rate of increase in body length of animals born in spring (spring generation). In autumn the highest point on the 

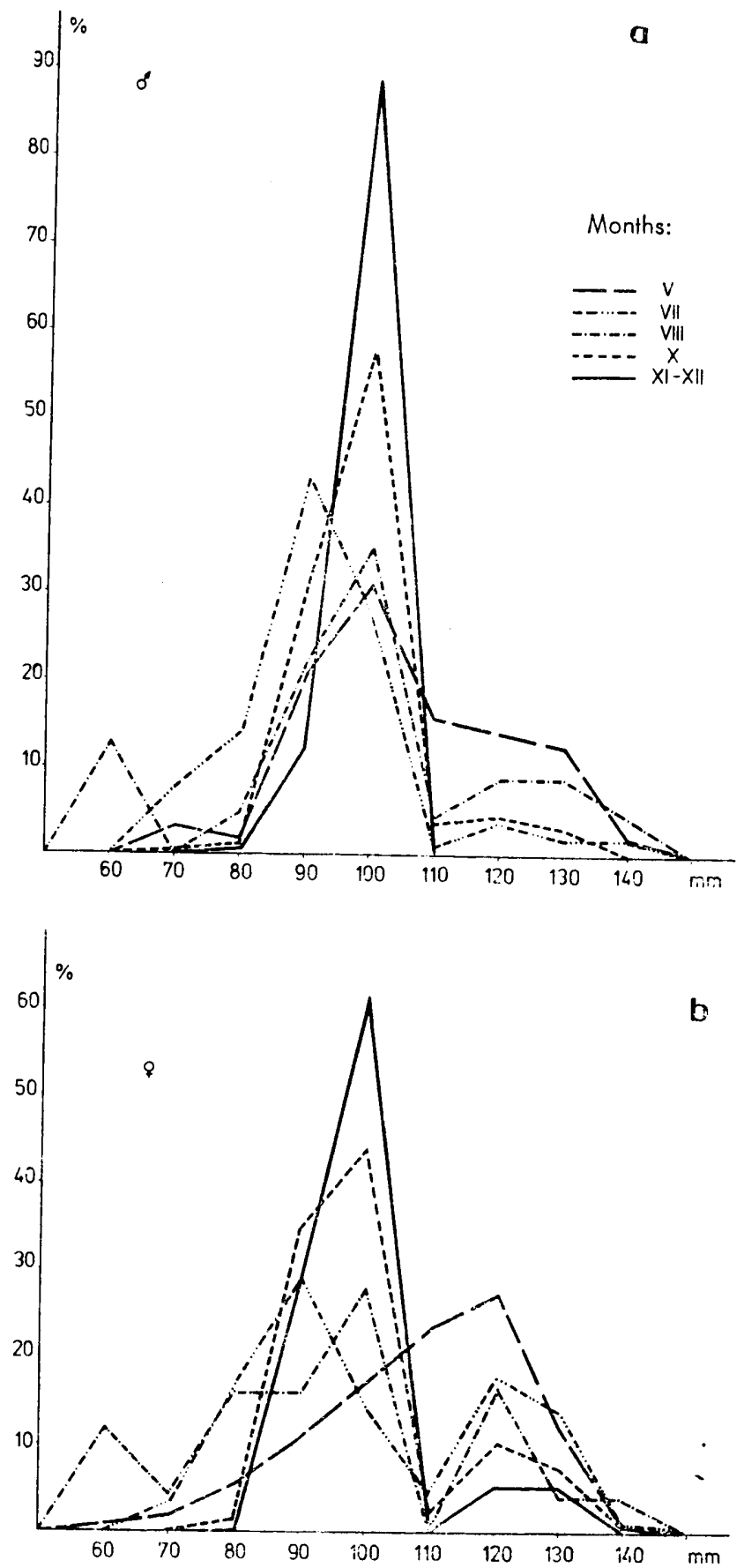

Fig. 5. Frequency distributions of body length of males (a), and females (b) in successive removals in 1966. 

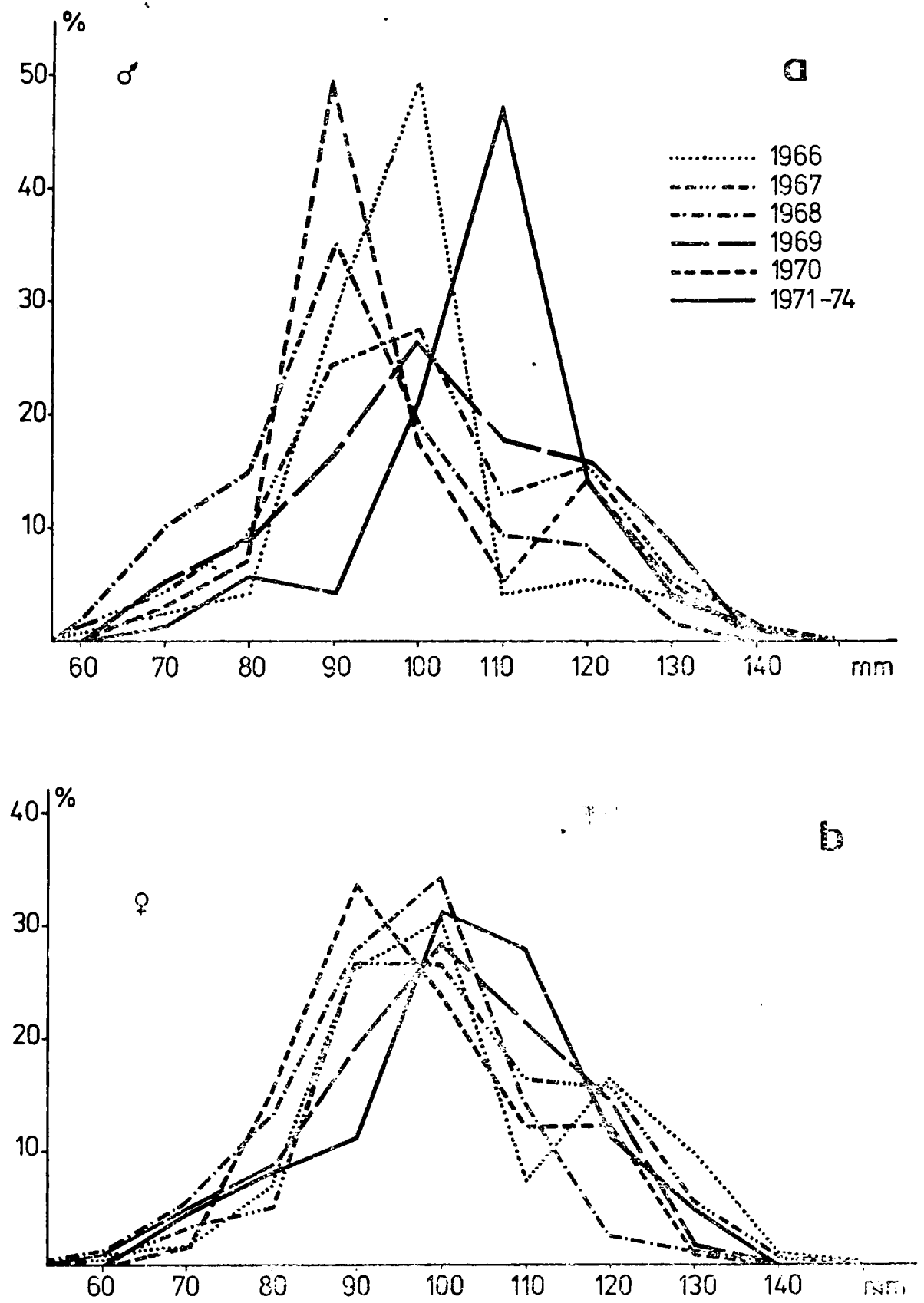

Fig. 6. Frequency distributions of body length in successive study years for males (a) and females (b). 
distribution is maintained at the same value as in August (Figs. 5a, b), due to the slower growth of these animals.

Variations in body length in successive years points to the differences in the two sexes (Figs. 6a, b). Distributions of body length in males are mcre differentiated and are distinguished by considerable shifts in the peaks. In the case of females distributions have one peak, and are flatter, except for the distribution from 1966, which has two distinct peaks. Distributions for 1971-74 for both sexes are different in character from the remainder, as they have one peak with decided negative skewness, due to the small number of young animals in the population (Figs. 6a, b).

Table 5

Statistical description of distributions of body length in males of age class $\mathrm{V}$ in successive study years.

\begin{tabular}{lcccrrr}
\hline \multicolumn{1}{c}{ Year } & $\overline{\mathrm{x}}$ & SD & Me & Mo & S & K \\
\hline 1966 & 125.74 & 7.24 & 126.00 & 126.52 & -0.75 & 4.58 \\
1967 & 120.61 & 7.07 & 121.30 & 122.68 & -0.22 & 2.45 \\
1968 & 110.60 & 8.84 & 109.70 & 107.89 & 0.14 & 2.03 \\
1969 & 121.26 & 6.45 & 120.85 & 120.03 & 0.09 & 2.04 \\
1970 & 115.00 & 8.64 & 115.50 & 116.50 & -0.04 & 1.98 \\
$1971-1974$ & 112.75 & 9.16 & 112.00 & 110.51 & 0.97 & 4.04 \\
\hline
\end{tabular}

There is a tendency to reduce the average value of body length in successive years (Table 5). This is not only the effect of percentage variations in age structure, since this is evident in each age class, and is particularly clear among old animals.

\subsubsection{Body Weight}

Body weight is sometimes used in field studies as an age criterion (Morris, 1972). In the vole it is possible to distinguish between individuals belonging to two generations. Analysis of frequency of body weight thus permits of tracing the variations in age structure which take place. As the body weight of females is disturbed by gestation, analysis of body weight was confined to males.

The distribution of male body weight frequencies has two peaks (Fig. 7a). Distributions for successive study years (Fig. 7b) reveal considerable differences in weight between young individuals and old adults. The lightest individuals appear in the population towards the end of July and in August, but as late as the beginning of October single individuals were caught weighing less than $10 \mathrm{~g}$. Individuals weighing over $45 \mathrm{~g}$ were caught from May to the end of September. 

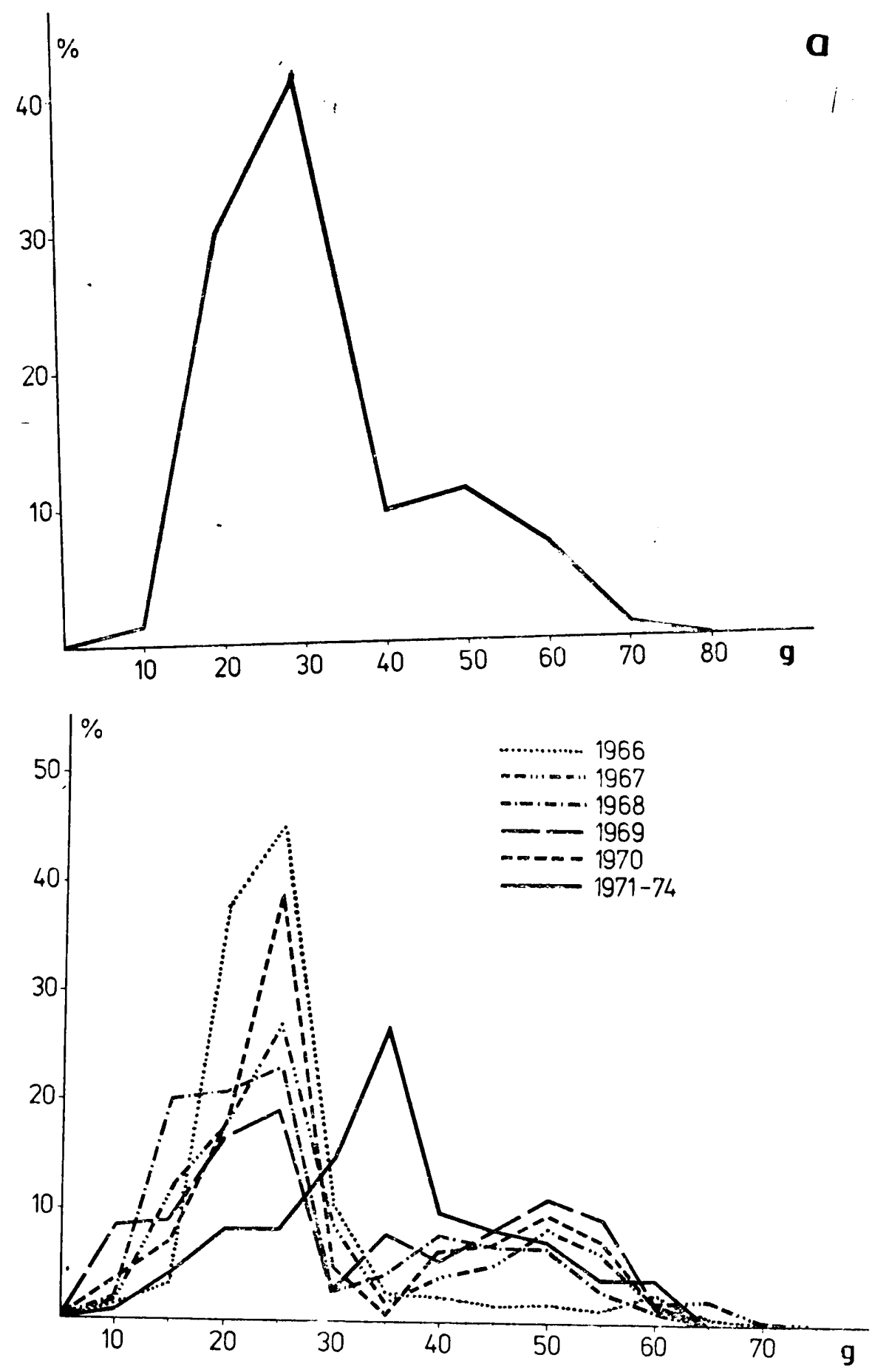

Fig. 7. Concluded on page 177. 


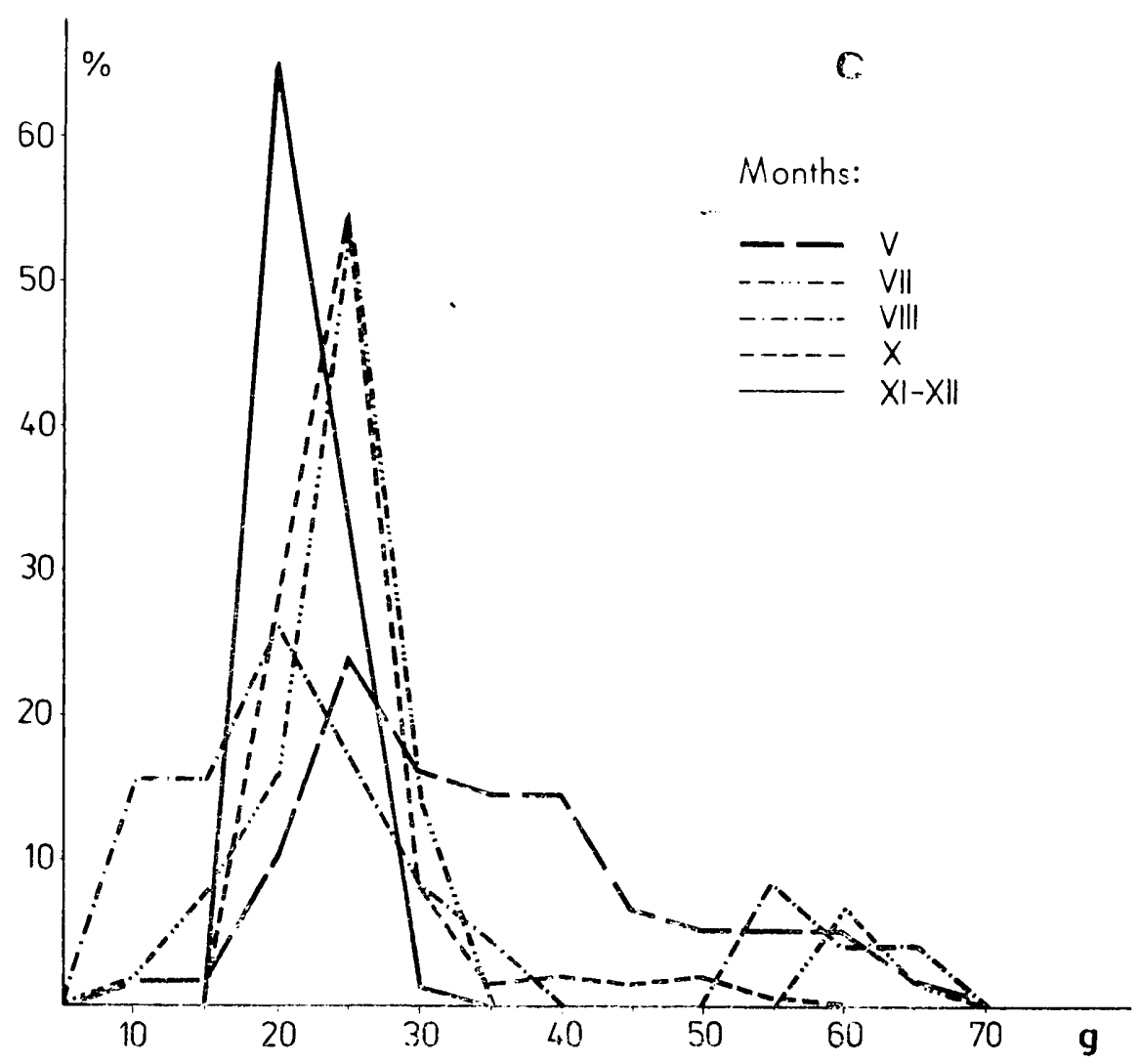

Fig. 7. Distributions of frequencies of body weight of males of the whole material (a), in successive study years (b), and successive removals in 1966 (c).

During the winter and early spring (from December to mid-April) increases in body weight in the population are slight. As from mid-April there is a rapid jump in growth lasting until the end of May - beginning of June. After attaining a maximum in July-August, there is a decrease in mean weight due to the disappearance of the heaviest individuals from the population (Figs. 2c, 3c).

Among young individuals in spring it is the females which are distinguished by the highest mean weights. In summer the mean value decreases, due to the entry into the population of new individuals. In early autumn the increase in mean weights is due to no young individuals entering the population, after which there is, however, a slight decrease (Figs. 2c, 3c). This can be seen clearly in the distributions of male body weights for 5 removals in 1966 (Fig. $7 \mathrm{c}$ ).

$A_{s}$ in the case of body length body weight exhibits a tendency to decrease in successive years (see section 3.4). 


\subsubsection{Condylobasal Length $(\mathrm{CbL})$.}

The distribution of $C B L$ frequencies shows two peaks, the first peak in both sexes occurring at the same value of $25 \mathrm{~mm}$, but the sacond is at $28 \mathrm{~mm}$ in males, and $27 \mathrm{~mm}$ in females. Dimorphic differences are not evident except in old individuals (Fig. 8a).
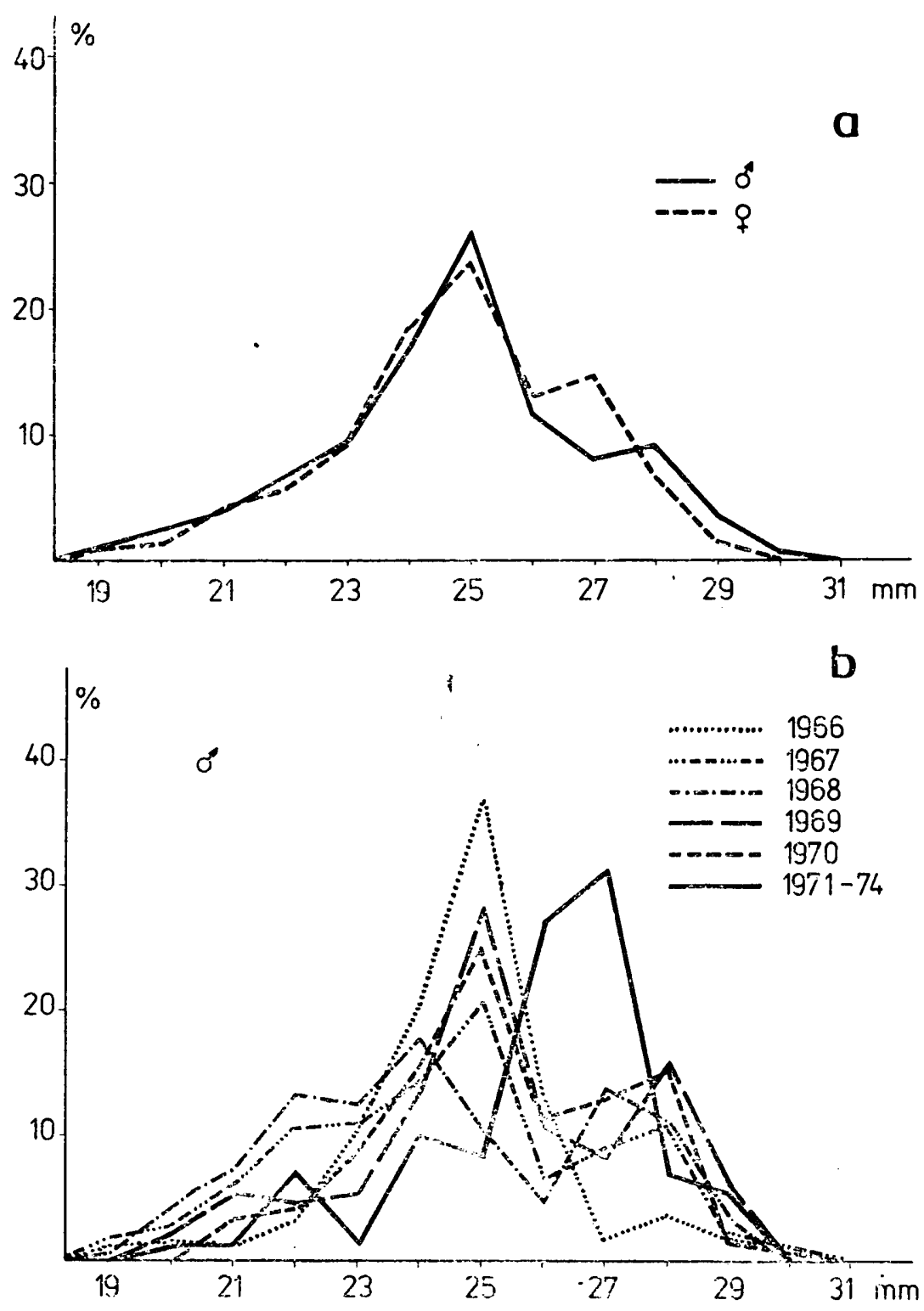

Fig. 8. Concluded on page 179. 


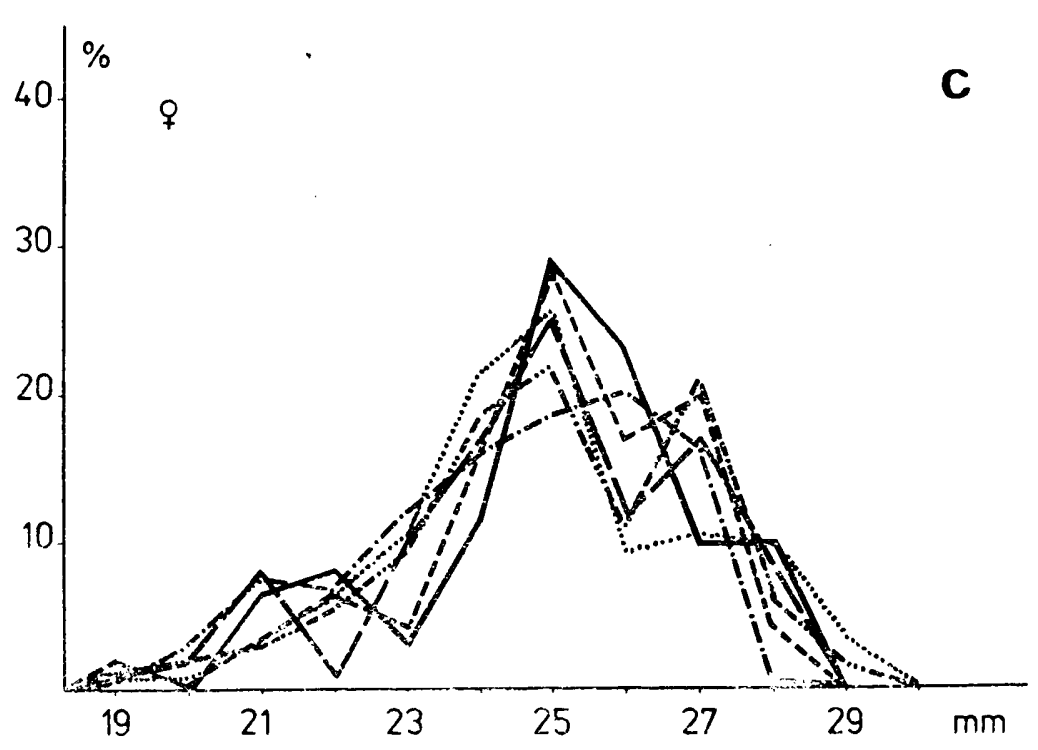

Fig. 8. Distributions of frequencies of condylobasal length ( $C b L$ ) for males and females (a) and in successive study years for males (b) and females (c).

During the spring and summer periods mean $C b L$ values among young individuals are higher for females, due to their more rapid weight growth connected with their earlier sexual maturation. Towards the end of summer, when reproduction ends, dimorphic differences in mean $C b L$ values are not significant, and in autumn the males have slightly higher mean values (Figs. 2d, 3d). In old individuals the mean $\mathrm{CbL}$ value is higher for males, but fluctuations in mean values follow an identical course in both sexes (Fig. 3d). In distributions of $\mathrm{CbL}$ frequency in males in successive years, two of them differ from the general picture: distribution for 1968 and for the years 1971-74 (Fig. 8b), as in the case of females (Fig. 8c).

\subsubsection{Diastema Length (DL)}

The distribution of $D L$ in the population has one peak in both sexes, with a shift towards maximum values in males. The distributions are characterized by slight negative asymmetry, sex dimorphism being more distinct in old adults in the form of a shift in $D L$ distributions in males towards maximum values (Ta'b. 6).

Fluctuations in monthly mean $D L$ values (Figs. $2 \mathrm{e}, 3 \mathrm{e}$ ) follow a similar course to that of fluctuations in $C b L$ mean values but, unlike them, no 
abrupt variations in values are observed, pointing to the more balanced growth of the diastema. This agrees with the observations made by W a silewski (1952) on the more even growth of the viscerocranium than the neurocranium in Clethrionomys glareolus.

\subsubsection{Brain-case Breadth $(B c B)$}

$B c B$ distribution in the population is similar in both sexes, but the distribution for males has higher frequencies, with higher values of the variable. Distributions are characterized by negative asymmetry and in females very high concentration of variables round the mean (Table 6). As in the case of $D L$, dimorphic differences are evident only in old adults, in the form of a shift in the distribution of $B c B$ in males towards maximum values (Table 6).

\section{Table 6}

Statistical description of distributions of some skull measurements $(D L, B c B, B c H)$.

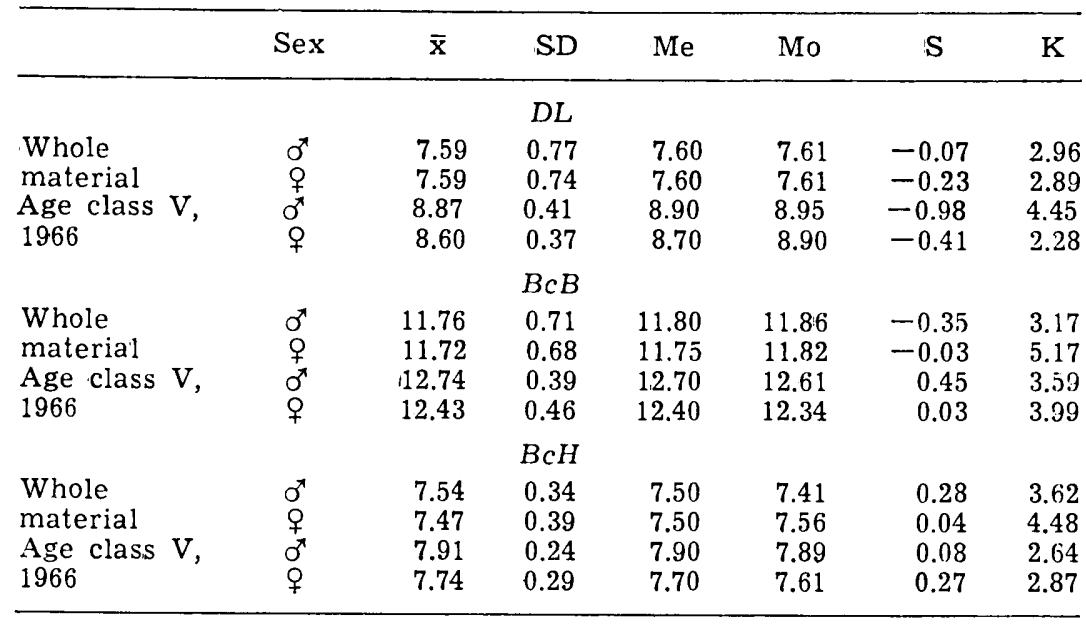

Variations in fluctuations of the monthly $B c B$ means in both generations are shown in Figures $2 f$ and $3 f$. In comparison with other parameters fairly great differences are evident in the mean values and growth rate for both sexes, being particularly distinct in old adults. Since, however, increase in the capacity of the brain-case with age is slight ( $\mathrm{M}$ a r k owski, in prep.), as has been shown by earlier data for other species of voles ( $\mathrm{Ruprecht}, 1974 ; \mathrm{Kratochvil}$ et al., 1977), the increases observed are due to the development of the bony nuchal crest and increase in thickness of the bone. 


\subsubsection{Brain-case Height ( $\mathrm{BcH})$}

BcH distribution in the population exhibits fairly considerable differences for both sexeis. In males it is similar to the normal distribution, whereas in females it is markedly leptokurtic with a very high concentration round the mean (Table 6). In addition the distribution for males is characterized by a shift towards maximum values.

Variations in fluctuations of monthly $\mathrm{BcH}$ mean values take a different course from the parameters so far discussed (Figs. 2g, 3g). Mean BcH

Table 7

Comparison of significance of differences in mean values of body and skull measurements in different age groups individuals of the spring and autumn generation, with $p=0.05$

\begin{tabular}{|c|c|c|c|c|c|c|}
\hline & \multicolumn{3}{|c|}{ Males } & \multicolumn{3}{|c|}{ Females } \\
\hline & $\mathrm{I}$ & II & III & I & II & III \\
\hline \multicolumn{7}{|l|}{ Body measurements } \\
\hline Body length & + & & + & & + & + \\
\hline Tail length & & & + & & + & + \\
\hline Hind foot & & & + & & & + \\
\hline Ear & & & & & & + \\
\hline Body weight & + & & + & + & + & + \\
\hline \multicolumn{7}{|l|}{ Skull measurements } \\
\hline$C b L$ & & * & * & & * & \\
\hline$B c L$ & & * & * & & $*$ & \\
\hline$D L$ & & & * & & & \\
\hline$M x T R L$ & & * & * & + & + & + \\
\hline $\begin{array}{l}M d L \\
B c B\end{array}$ & & * & * & & & \\
\hline$Z y B$ & & & & & + & + \\
\hline IC & & & $*$ & & & \\
\hline$R B$ & & & + & & + & + \\
\hline$B c H$ & & & + & & & + \\
\hline Eye lens weight & & $*$ & $*$ & & * & $*$ \\
\hline
\end{tabular}

values in each age class exhibit a tendency to decrease during the period from spring to autumn (Fig. 9), mean $\mathrm{BcH}$ values for individuals of the spring and autumn generations (age class 3) differing to a statistically significant degree (Table 7). The Hrdlička-Kočka index which accurately represents the proportions of the neurocranium, also exhibits fairly considerable decrease in the generation of young individuals (Fig. 10). 


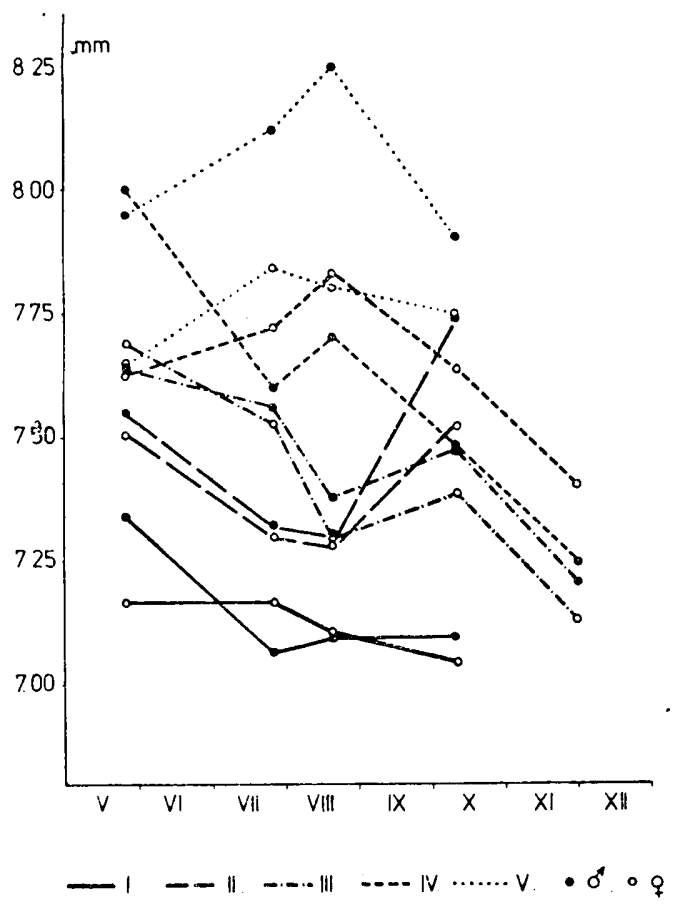

Fig. 9. Variations in arithmetical means for brain-case height values in age classes for successive removals in 1966.

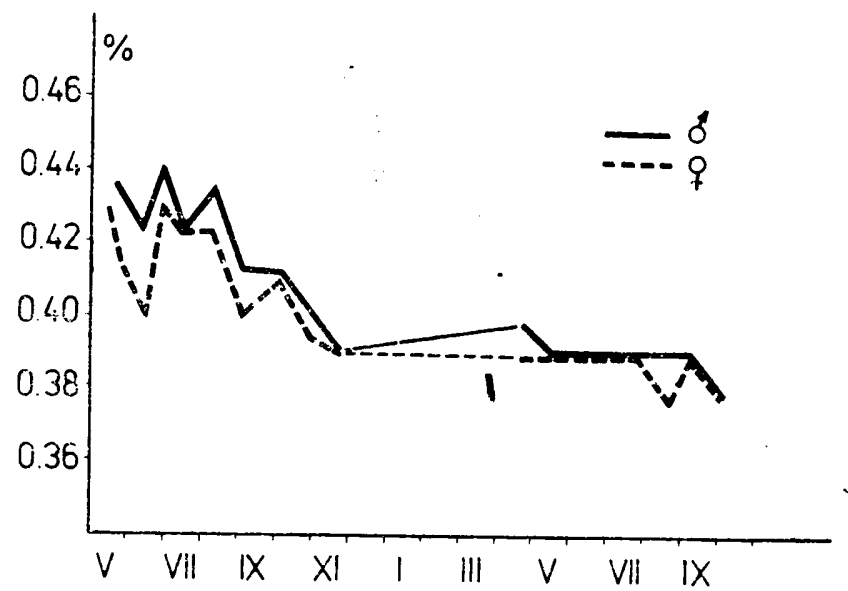

Fig. 10. Variations in mean values of Hrdlička-Kočka index for two generations. The diagram was plotted on the basis of arithmetical means calculated for different months, using data for the period 1966-1974. 
These variations in mean $\mathrm{BcH}$ values over the annual cycle are similar to variations found earlier for this species by Wasile wski (1956b). This author suggests the existence of the phenomenon of skull depression (Dehnel's phenomenon) characteristic of Sorex and Neomys (Dehnel, 1949; Pucek, 1963). Similar decrease in mean $B c H$ values have been observed in other species of rodents (W a silewski,

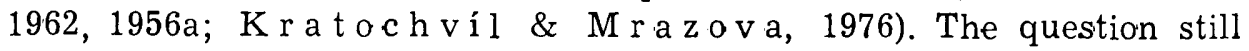
remains open, however, as to whether in the case of Microtidae we have to do with a phenomenon analogical to the winter depression in the skull of Soricidae.

The decrease in $\mathrm{BcH}$ value observed in old adults in autumn is connected wtih decrease in the mean value of lens weight and is due to the oldest individuals disappearing from the population. The situation among individuals of the young generation is far more complicated, since it was found that there is a similar relation during the summer period and in spring in age class III (Table 8). It is thus clear that the

\section{Table 8}

Mean values of braincase height depending on eye lens weight in individuals in age class III (taking 1966 as an example)

\begin{tabular}{|c|c|c|c|c|c|c|c|c|c|c|}
\hline & • & $\begin{array}{l}\infty \\
\infty \\
\text { i }\end{array}$ & 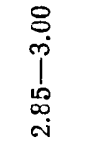 & 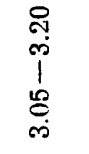 & 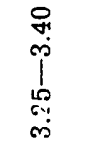 & $\begin{array}{l}\stackrel{8}{\bullet} \\
\text { ip } \\
1 \\
\dot{10} \\
\dot{10}\end{array}$ & 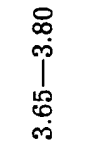 & $\begin{array}{l}8 \\
\stackrel{8}{+} \\
1 \\
1 \\
\infty \\
\dot{m} \\
\dot{m}\end{array}$ & 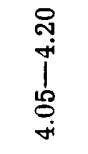 & $\stackrel{\text { : }}{\stackrel{+}{+}}$ \\
\hline Spring & $\frac{\mathrm{n}}{\overline{\mathrm{x}}}$ & $\begin{array}{l}17 \\
\quad 7.72\end{array}$ & $\begin{array}{l}14 \\
\quad 7.66\end{array}$ & $\begin{array}{l}7 \\
7.61\end{array}$ & $\begin{array}{l}9 \\
7.58\end{array}$ & $\begin{array}{l}6 \\
7.40\end{array}$ & $\begin{array}{l}5 \\
7.42\end{array}$ & $\begin{array}{l}5 \\
7.30\end{array}$ & & \\
\hline Summer & $\overline{\mathrm{x}}$ & $\begin{array}{l}11 \\
7.47\end{array}$ & $\begin{array}{l}12 \\
7.55\end{array}$ & $\begin{array}{l}10 \\
7.40\end{array}$ & $\begin{array}{l}8 \\
7.46\end{array}$ & $\begin{array}{l}6 \\
7.42\end{array}$ & $\begin{array}{l}5 \\
7.34\end{array}$ & & & \\
\hline Autumn & $\frac{\mathrm{n}}{\overline{\mathrm{x}}}$ & 8 & $\begin{array}{l}7 \\
7.36\end{array}$ & $\begin{array}{l}14 \\
7.31\end{array}$ & $\begin{array}{l}26 \\
7.33\end{array}$ & $\begin{array}{l}20 \\
7.34\end{array}$ & $\begin{array}{c}36 \\
7.37\end{array}$ & $\begin{array}{l}47 \\
\quad 7.30\end{array}$ & $\begin{array}{l}57 \\
\quad 7.29\end{array}$ & $\begin{array}{c}11 \\
7.30\end{array}$ \\
\hline
\end{tabular}

phenomenon of skull depression as the lens weight increases occurs constantly, irrespective of the time of the year and must be of a different nature than Dehnel's phenomenon. The flattening of the skull may thus be the effect of the action of forces on the vault of the neurocranium as the base of the skull grows. Gębczyniska (1964) explains the effect of reduction in brain-case height similarly for $M$. agrestis kept in captivity.

\subsection{Variability of Dimensions}

The values of coefficients of variation in different parameters change with age. Generally high values of these coefficients are found in age class I, then a decrease in age classes II and III, after which they 
attain higher values in classes IV and $\mathrm{V}^{1}$. In age class $\mathrm{I}$ there is a tendency to reduction in $C V$ value with the passage of successive years. This is connected with the gradual reduction in the percentage of "nest « individuals in this class. In the remaining age classes the CV values are higher in years with lower population numbers, i.e. in 1968 , and for the combined sample comprising individuals for the years 1971-74.

Reduction in ranges of variability were observed in all body and skull measurements in successive years of removal. This is illustrated by diagrams of frequency of head and boidy (Fig. 6a, b), body weight (Fig. 7c) and $\mathrm{CbL}$ (Fig. 8b, c). Mean reduction in ranges over the period from 1966-1974 was as follows: for head and body $-16.2 \%$ for males and $28.9 \%$ for females; for body weight correspondingly 23.9 and $19.7 \%$; for $C b L-26.6$ and $29.4 \%$. For some of the skull dimensions reduction in ranges is even more distinct, e.g. for zygomatic breadth it is over $36 \%$ in both sexes. This is directly connected with reduction in population numbers.

\subsection{Variability in Mean Values}

Comparison of the significance of diferences between mean values (with $p=0.05$ ) cf body and skull dimensions in successive years was preceded by tes.ing the homogeneity of the age classes compared on the basis of dry lens weight (age criterion). It was found that out of the 150 comparisons made, in 13 cases (i.e., 8.6\%) differences were significant $(P<0.05)$. The occurrence of these differences is due to the high degree of variability in lens weight which becomes evident when using small samples.

Analysis of statistical differences between means of different dimensions between successive years revealed a certain alternation in increase or reduction of the number of significant differences. The question therefore arises as to whether this alternation is cylic in the study population and what is the relation between it and the cycle. of variations in numbers. For this purpose use was made of the method proposed by $\mathrm{Krebs}$ (1964b) of analysis of variations in mean deviations from linear regression of body length $-\mathrm{Cb}$ length, making allowance for division into season and age.

Variations in mean deviation from linear regression of the summer period were related to the calculated densities (B uchalczyk \&

1 Tabular comparison of coefficients of variation for measurements of the body and skull between successive years has not been included in this paper, but the typescript is available from the author and is to be found in the Library of the Mammals Research Institute PAS at Białowieża. 
\& P u c e k, 1968). The application as from 1969 of the uniform trapping system permits of accepting the index of trappability as a measure of variations in population numbers in succeeding years.

The results obtained point to a certain lack of agreement between the
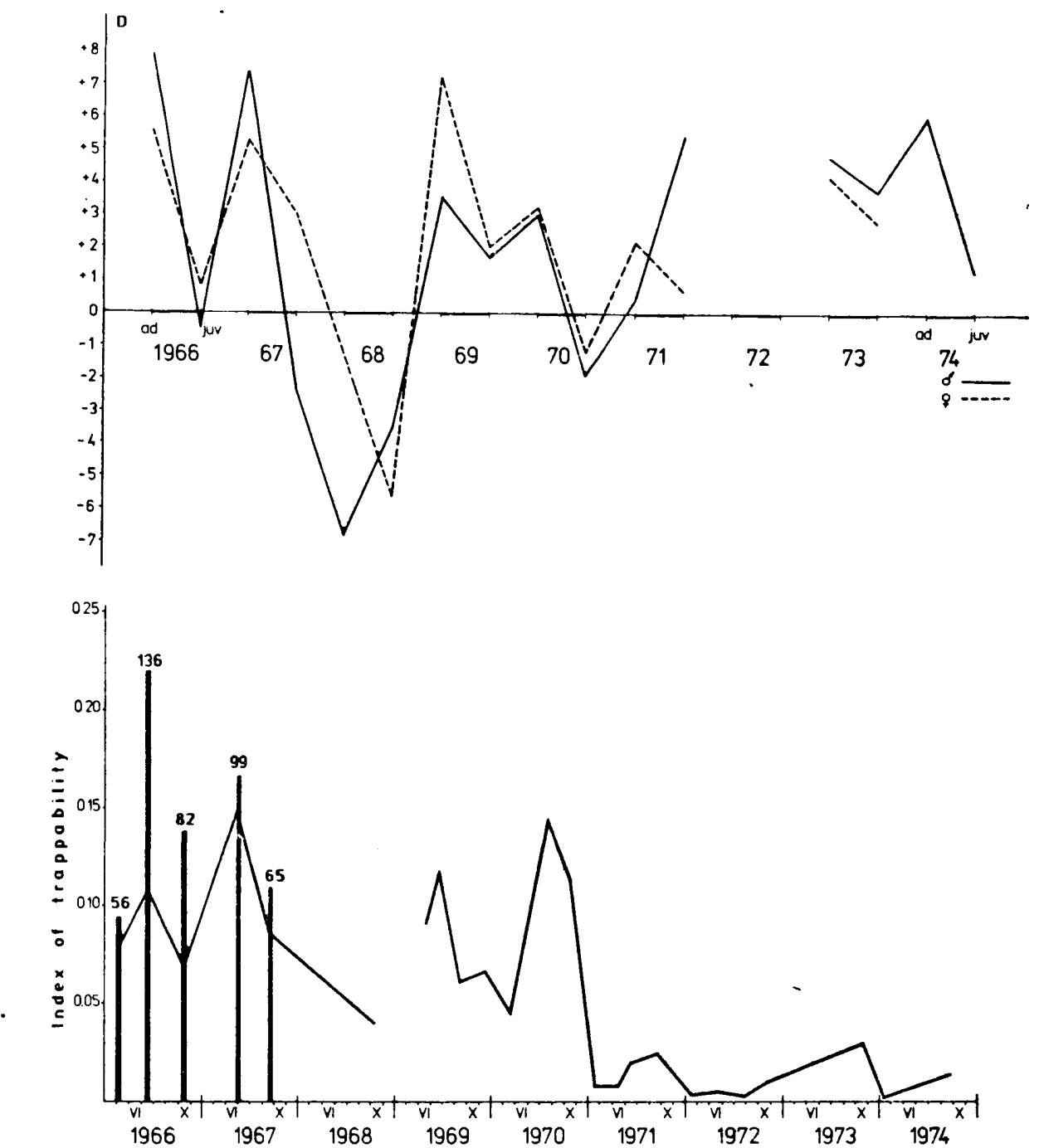

Fig. 11. Variations in values of mean deviations from straight-line regression for body length - $\mathrm{Cb}$ length, during summer in males and females in successive years, taking into consideration young individuals and old adults, and variations in the trappability index of $M$. oeconomus in successive years, calculated separately for Standard Minimum area $(1966-68)$ and permanent trapping lines as from 1969. Columns and figures above them illustrate density (n/ha) for $M$. oeconomus estimated by means of the Standard Minimum method (data from the paper by Buchalczyk \& Pucek, 1968). 
maximum dimensions obtained in 1969 and the peak numbers which occurred a year later (Fig. 11). In the study population two reductions in numbers were reconded in 1968 and 1972, the first of which is in agreement with reduction in dimensions of body size, and in the second case only 3 individuals were caught, making it pointless to give deviations for them.

When comparing the significance of differences between mean values of the different dimensions, a tendency was also observed to reduction in their value in successive years. The results of testing the significance of the tendency to decrease in coefficients of regression within age class $\mathrm{V}$ are given in Table 9. The decrease in mean dimensions in the

\section{Table 9}

Comparison of results of testing tendency to decrease, with $p=0.05$, of some body and skull measurements in males and females in age class $\mathrm{V}$ in successive years of the study.

\begin{tabular}{|c|c|c|c|c|}
\hline \multirow[t]{2}{*}{ Measurement } & \multirow[t]{2}{*}{ Sex } & \multirow[t]{2}{*}{$\begin{array}{l}\text { Equation of } \\
\text { decrease } \\
\text { tendency }\end{array}$} & \multicolumn{2}{|c|}{$\begin{array}{l}\text { Significance of } \\
\text { equation coefficients } \\
\text { testing }\end{array}$} \\
\hline & & & $a$ & $b$ \\
\hline \multirow{4}{*}{$\begin{array}{l}\text { Eye lens dry } \\
\text { weight } \\
\text { Body length }\end{array}$} & $\sigma^{x}$ & $y=5.73-0.083 x$ & + & - \\
\hline & 웅 & $y=5.67-0.046 x$ & + & - \\
\hline & $\stackrel{+}{\sigma^{4}}$ & $y=122.52-2.11 x$ & $\dot{t}$ & + \\
\hline & $q$ & $y=118.79-2.43 x$ & + & + \\
\hline \multirow{2}{*}{ Body weight } & $\sigma^{\pi}$ & $y=50.75-1.85 x$ & + & + \\
\hline & $q$ & $y=44.14-1.51 x$ & + & + \\
\hline \multirow{2}{*}{$\mathrm{CbL}$} & $0^{x}$ & $y=28.15-0.156 x$ & + & 一 \\
\hline & q & $y=27.25-0.069 x$ & + & - \\
\hline
\end{tabular}

+ Regresion equation coefficients significantly different from 0 .

- Regression equation coefficients not significantly different from 0 .

younger age classes was not taken into consideration, although in the case of $B w t$ or body length they were statistically significant $(P<0.05)$. The decrease observed in these age classes may be due to the different dates at which reproduction began, or is the effect of quantitative differences between individuals of the spring or autumn generation.

Only'the decrease in mean values of body length and body weigh: proved to be statistically significant (Fig. 12) in both sexes of age class $\mathrm{V}$ in successive years. Values $t$ of angle coefficients of linear regression of the two dimensions differed significantly from zero $(P<0.05)$. The tendency to decrease in the value of average lens weight and $C b L$ proved not to be significant $(P>0.05)$ (Table 9). Tendencies for other skull dimensions such as $B c L, Z y B$ also proved not to be significant, but have not been included in Table 9 . 
The results obtained show that the dimensions of the skeleton in $M$. oeconomus are stable and are subject to a lesser degree to habitat factors than are body dimensions, which in successive years may differ considerably. A similar relation has been found in other rodents, e.g., in Pitymys subterraneus by W a sile wski (1960).

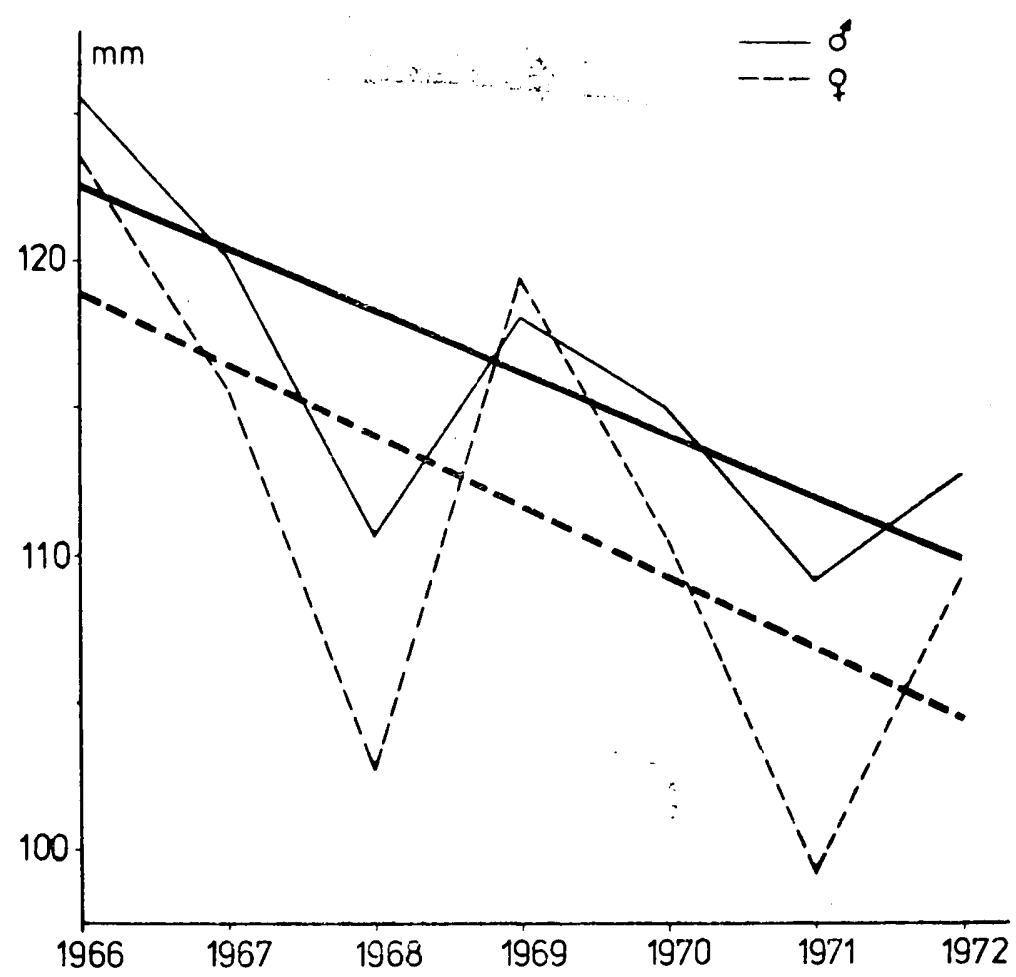

Fig. 12. Variations in arithmetical means of body length for males and females in age class $\mathrm{V}$ in successive study years and straight lines of regression based on these values.

\subsection{Variability in Seasonal Generations}

Two generations can be distinguished on the strength of morphological characteristics in the study population, namely the spring and autumn generations. Individuals of both sexes of the former generation are significantly larger than individuals of the autumn generation in respect of body dimensions (Table 7). These differences are less distinct in skull measurements. Males of the spring generation have significantly greater mean $R B$ and $B c H$ values $(P<0.05)$, while those of the autumn generation have significantly greater $C b L$. Females of the spring generation have significantly greater $R B, B c H, Z y B$ and $M x T R L$. In 

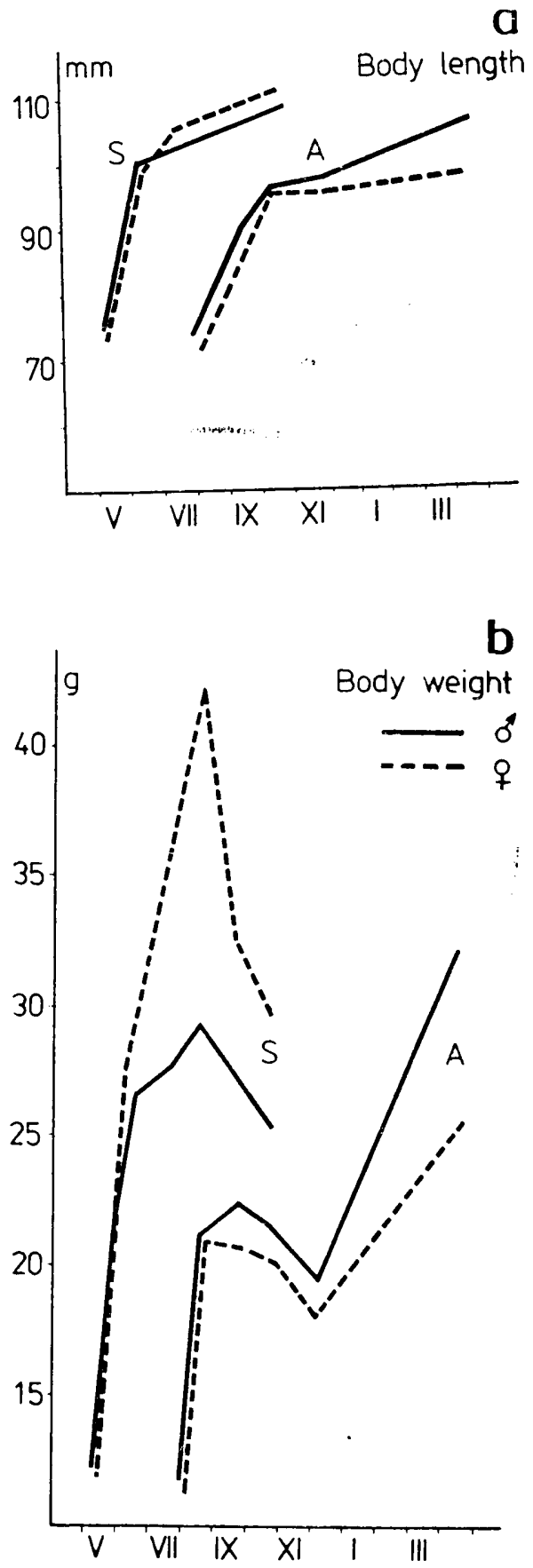

Fig. 13. Concluded on page 189. 


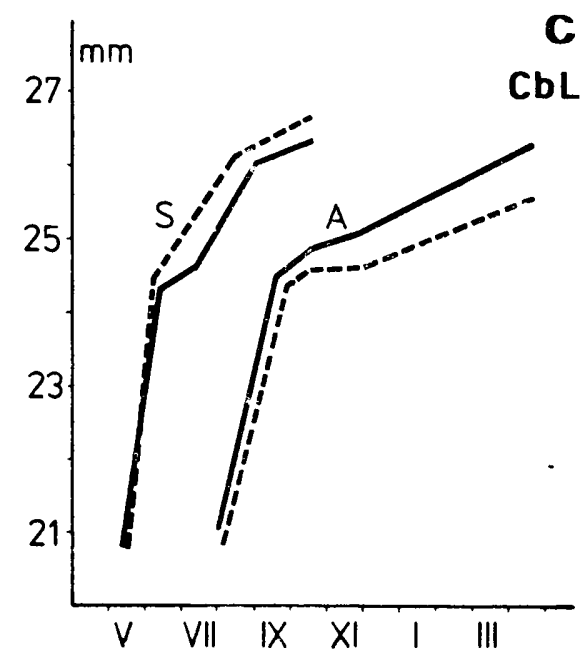

Fig. 13. Mean growth rate of body length (a), body weight, (b), and $C b L$ (c) in individuals of the spring (S) and autumn (A) generations.

respect of the remaining dimensions the mean values for the autumn generation are statistically higher (Table 7).

The two generations distinguished are also characterized by difference in growth rate. Individuals of the spring generation grow more intensively and attain maximum dimensions within $\mathbf{4}-\mathbf{5}$ months (up to $110 \mathrm{~mm}$ body length, 26.5 $\mathrm{CbL}, 30 \mathrm{~g}$ body weight in males and $40 \mathrm{~g}$ in females - Fig. 13). Individuals of the autumn generation grow intensively only for about 2.5 months, after which their rate of growth slows consideralbly. Some parameters even exhibit a decrease in mean values, e.g.: body weight and $\mathrm{BcH}$ (Fig. 13).

\subsection{General Biometric Description}

Considerable variability was found in body and skull dimensions in the root vole population studied, due to the successively alternating generations, differences in growth in successive years and gradual reduction in body measurements. Despite this, it was decided to give a general biometric description in the age classes distinguished on the basis of the available material (Table 10). 
Table 10

Body measurements, skull measurements and quotient indices in different age

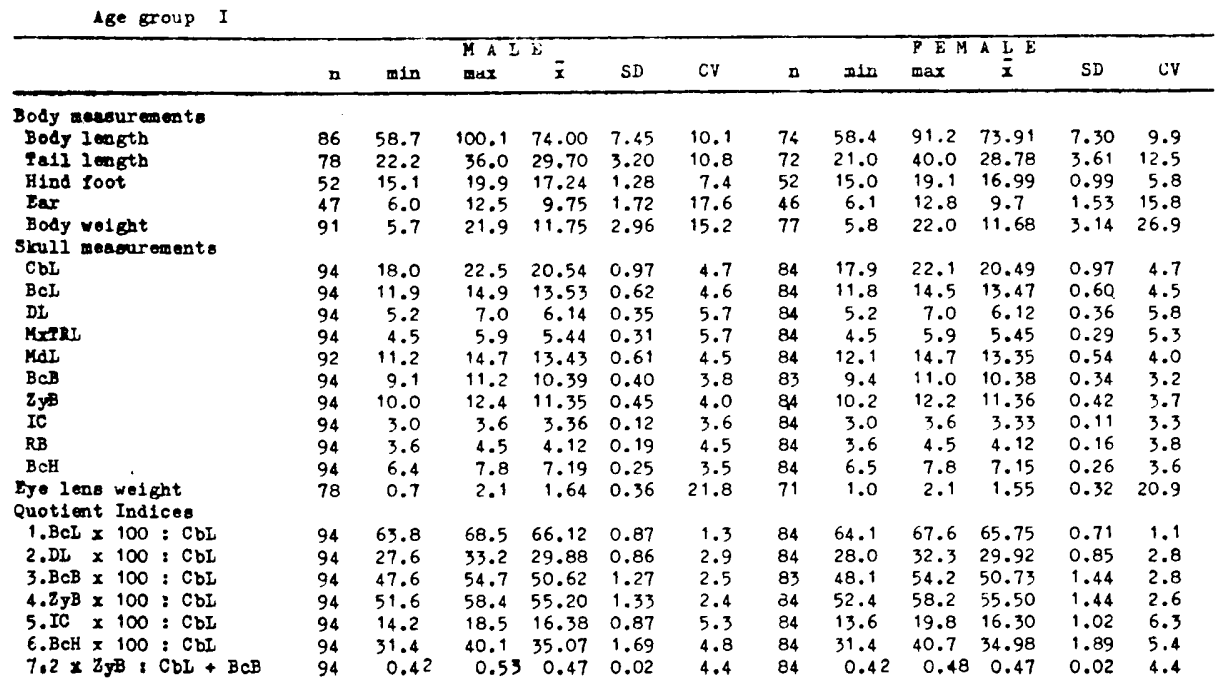

Age group II

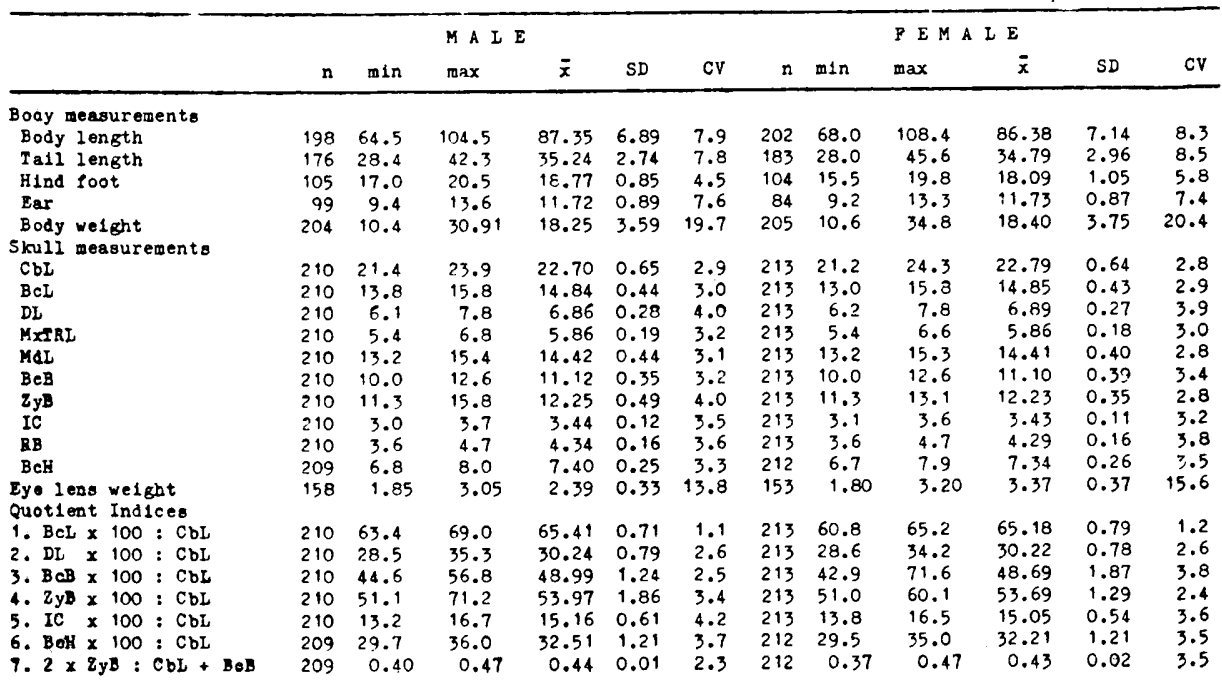


classes of $M$. oeconomus.

Age eroup III

\begin{tabular}{|c|c|c|c|c|c|c|c|c|c|c|c|c|}
\hline & \multicolumn{5}{|c|}{$M A L E$} & \multicolumn{7}{|c|}{ FEMALE } \\
\hline & $\mathrm{n}$ & $\min$ & $\max$ & $\bar{x}$ & SD & CV & 7 & $m \perp n$ & $\max$ & $\overline{\boldsymbol{x}}$ & $S D$ & $\mathrm{cV}$ \\
\hline \multicolumn{13}{|l|}{ Body measurements } \\
\hline Body length & sos & 80.0 & 119.7 & 96.59 & 6.06 & 6.3 & 482 & 81.0 & 114.0 & 97.38 & 6.01 & 6.2 \\
\hline Tall length & 479 & 26.2 & 51.0 & 38.82 & 3.26 & 8.4 & 472 & 27.5 & 59.0 & 38.83 & 4.23 & 10.9 \\
\hline Hind foot & 70 & 16.7 & 22.7 & 19.29 & 0.94 & 4.9 & 295 & 16.6 & 21.5 & 18.79 & 0.90 & 4.8 \\
\hline Ear & 256 & 10.0 & 14.8 & 12.46 & 0.78 & 6.3 & 270 & 10.0 & 17.4 & 12.49 & 0.91 & 7.3 \\
\hline Body welght & 515 & 14.8 & 46.7 & 22.63 & 4.69 & 20.7 & 486 & 12.5 & 50.3 & 23.73 & 7.62 & 32.1 \\
\hline \multicolumn{13}{|l|}{ Skull measurements } \\
\hline $\mathrm{CbL}{ }^{\circ}$ & 526 & 23.3 & 26.6 & 24.75 & 0.61 & 2.5 & 492 & 23.2 & 26.4 & 24.67 & 0.60 & 2.4 \\
\hline BcI & 526 & 14.9 & 16.9 & 16.02 & 0.39 & 2.4 & 492 & 12.9 & 17.2 & 15.98 & 0.43 & 2.7 \\
\hline DL & 526 & 6.8 & 8.3 & 7.57 & 0.27 & 3.6 & 492 & 6.0 & 8.4 & 7.52 & 0.28 & 3.7 \\
\hline MxTRL & 526 & 5.3 & 6.7 & 6.15 & 0.20 & 3.2 & 492 & 5.0 & 6.9 & 6.15 & 0.20 & 3.2 \\
\hline $\operatorname{MdL}$ & 525 & 14.0 & 16.9 & 15.36 & 0.44 & 2.9 & 491 & 14.3 & 16.6 & 15.36 & 0.42 & 2.8 \\
\hline $\mathrm{BCB}$ & 526 & 10.0 & 12.6 & 11.78 & 0.32 & 2.7 & 492 & 10.8 & 12.6 & 11.71 & 0.31 & 2.6 \\
\hline $2 \mathrm{yB}$ & 525 & 11.9 & 14.7 & 13.09 & 0.42 & 3.2 & 491 & 12.0 & 14.5 & 13.11 & 0.42 & 3.2 \\
\hline IC & 525 & 3.2 & 3.9 & 3.53 & 0.11 & 3.2 & 492 & 3.2 & 3.8 & 3.49 & 0.11 & 3.1 \\
\hline RB & 525 & 3.5 & 5.1 & 4.51 & 0.16 & 3.6 & 492 & 4.2 & 5.0 & 4.50 & 0.16 & 3.6 \\
\hline $\mathrm{BcH}$ & 526 & 6.7 & 8.3 & 7.48 & 0.25 & 3.3 & 491 & 6.2 & 8.2 & 7.42 & 0.25 & 3.4 \\
\hline Eye lens weight & 418 & 3.05 & 4.30 & $\times .69$ & 0.53 & 14.4 & 406 & 3.10 & $4 \cdot 30$ & 3.63 & 0.59 & 16.2 \\
\hline Quotient Indices & & & & & & & & & & & & \\
\hline $1 . \mathrm{BCL} \times 100: \mathrm{CbL}$ & 526 & 60. & 6 & .7 & 0.68 & 1.1 & 492 & 53.3 & 69.3 & 64.75 & 0.97 & -1.5 \\
\hline 2.DL $\times 100: \mathrm{CbL}$ & 526 & 27.7 & 33.2 & 30.57 & 0.63 & 2.3 & 492 & 25.5 & 33.2 & 30.46 & 0.73 & 2.4 \\
\hline $3 . \mathrm{BcB} \times 100: \mathrm{CbL}$ & 526 & 39.1 & 50.8 & 47.6 & 1.23 & 2.6 & 492 & 28.9 & 50.6 & 47.42 & 1.41 & 3.0 \\
\hline $4.2 \mathrm{yB} \times 100: \mathrm{CbL}$ & 525 & 48.2 & 58.8 & 52.91 & 1.35 & 2.6 & 491 & 50.0 & 59.4 & 53.14 & 1.30 & 2.5 \\
\hline $5 . I C \times 100: \mathrm{CbL}$ & 526 & 12.6 & 15.9 & 14.28 & 0.55 & 3.8 & 492 & $1 \hat{c} . \theta$ & 15.6 & 14.16 & 0.59 & 4.2 \\
\hline $6 . \mathrm{BcH} \times 100: \mathrm{CBL}$ & 526 & 26.0 & 33.8 & 30.25 & 1.20 & 4.0 & 491 & 24.8 & 35.7 & 30.13 & 1.53 & 5.1 \\
\hline $72 \times 2 \mathrm{gB}: \mathrm{CDI}+$ & 526 & 0.36 & 0.45 & 0.41 & 0.02 & 3.7 & 491 & 0.33 & 0.45 & $0.4 i$ & 0.02 & 4.9 \\
\hline
\end{tabular}

IGe eroup IT

\begin{tabular}{|c|c|c|c|c|c|c|c|c|c|c|c|c|}
\hline - & n & $\min$ & $\underset{\max }{A} \hat{A} L E$ & $\overline{\mathbf{x}}$ & SD & $\mathrm{cr}$ & n & $\min$ & $\begin{array}{l}F B M \\
\max \end{array}$ & $I^{I} \frac{B}{x}$ & SD & $\mathrm{CV}$ \\
\hline \multicolumn{13}{|l|}{ Body mesuremonto } \\
\hline Body longth & 135 & 90.5 & 129.3 & 107.86 & 9.10 & 8.4 & 158 & 90.0 & 129.8 & 111.88 & 9.30 & 8.3 \\
\hline Tall length & 132 & 31.9 & 57.4 & 45.12 & 4.68 & 10.4 & 147 & 33.2 & 55.5 & 46.88 & 4.76 & 10.2 \\
\hline Hind foot & 83 & 17.4 & 21.0 & 19.76 & 0.77 & 3.9 & 96 & 16.8 & 21.1 & 19.12 & 0.97 & 4.8 \\
\hline Ear & 74 & 11.5 & 15.2 & 13.21 & 0.69 & 5.3 & 83 & 11.2 & 17.3 & 13.42 & 1.06 & 7.9 \\
\hline Body welght & $1 \geqslant 7$ & 20.0 & 54.9 & 35.25 & 9.57 & 27.1 & 165 & 16.9 & 74.2 & 38.13 & 9.55 & 25.0 \\
\hline \multicolumn{13}{|l|}{ Srull neasurements } \\
\hline $\mathrm{CbI}$ & 141 & 24.6 & 27.7 & 26.55 & 0.56 & 2.1 & 167 & 24.6 & 27.9 & 26.61 & 0.58 & 2.2 \\
\hline BcL & 141 & 15.8 & 17.9 & 17.02 & 0.35 & 2.1 & 167 & 15.8 & 18.2 & 17.04 & 0.70 & 4.1 \\
\hline DL & 141 & 7.5 & 8.9 & 8.17 & 0.27 & 3.3 & 167 & 7.4 & 9.0 & 8.26 & 0.28 & 3.4 \\
\hline MrTRL & 141 & 5.7 & 6.8 & 6.35 & 0.20 & 3.2 & 167 & 5.6 & 7.1 & 6.38 & 0.22 & 3.5 \\
\hline MdL & 140 & 15.3 & . 17.0 & 16.11 & 0.35 & 2.2 & 167 & 15.3 & 17.0 & 16.30 & 0.46 & 2.8 \\
\hline $8 \mathrm{cB}$ & 141 & 11.2 & 12.9 & 12.26 & 0.33 & 2.7 & 167 & 11.7 & 13.0 & 12.29 & 0.29 & 2.4 \\
\hline Zyв & 141 & 13.0 & 15.4 & 14.13 & 0.55 & 3.9 & 167 & 12.4 & 15.5 & 14.37 & 0.52 & 3.7 \\
\hline IC & 141 & $3.2^{\circ}$ & 3.8 & 3.58 & 0.13 & 3.7 & 167 & 3.0 & 3.8 & 3.53 & 0.12 & 3.4 \\
\hline RB & 141 & 4.3 & 5.5 & 4.88 & 0.24 & 4.9 & 167 & 3.7 & 5. & 4.85 & 0.22 & 4.5 \\
\hline $\mathrm{BcH}$ & 141 & 7.0 & 8. & 7.67 & 0.30 & 3.9 & 167 & 7.0 & 8.1 & 7.63 & 0.24 & 3.1 \\
\hline Byo lene welght & 122 & 3.80 & 5.20 & 4.28 & 0.37 & 8.6 & 141 & 3.80 & 5.20 & 4.22 & 0.39 & 9.2 \\
\hline \multicolumn{13}{|l|}{ Quotient Indices. } \\
\hline 1. BCL $\times 100: C b L$ & 141 & 61.7 & 65.5 & 64.34 & 0.66 & 1.0 & 167 & 61.8 & 65.3 & 64.22 & 0.67 & 1.0 \\
\hline 2. DL $\times 100: \mathrm{CbI}$ & 141 & 28.9 & 33. & 30.80 & 0.68 & 2.2 & 167 & 27.7 & 33.9 & 31.02 & 0.74 & 2.4 \\
\hline 3. $\mathrm{BCB} \times 100: \mathrm{CbL}$ & 141 & 41.3 & 48.9 & 46.35 & 1.37 & 3.0 & 167 & 43.7 & 49.6 & 46.18 & 1.06 & 2.3 \\
\hline 4. $2 \mathrm{yB} \times 100: \mathrm{CbL}$ & 141 & 50.0 & 57.5 & 53.39 & 1.56 & 2.9 & 167 & 47.7 & 56.9 & 53.99 & 1.52 & 2.8 \\
\hline 5. IC $\times 100: C B E$ & 141 & 12.1 & 14.7 & 13.55 & 0.56 & 4.2 & 167 & 11.1 & 14. & 13.27 & 0.81 & 6.1 \\
\hline 6. $\mathrm{BeH} \times 100: \mathrm{CbL}$ & 141 & 25.4 & 32.5 & 29.02 & 1.15 & 3.9 & 167 & 25.9 & 31.7 & 28.67 & 0.99 & 3.4 \\
\hline 7. $2 \times 2 \mathrm{yB}: \mathrm{CBL}+\mathrm{B}$ & 141 & 0.36 & 0.44 & 0.40 & 0.01 & 3.7 & 167 & 0.36 & 0.43 & 0.39 & 0.01 & 3.2 \\
\hline
\end{tabular}




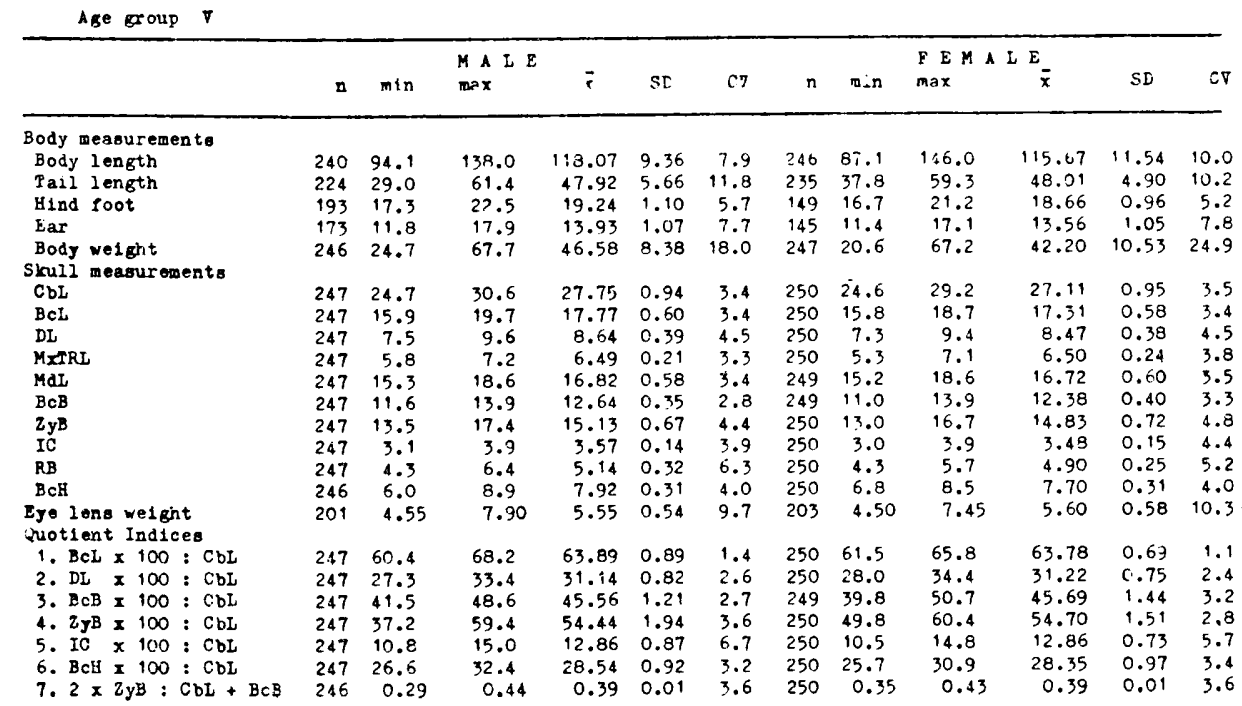

\section{DISCUSSION}

\subsection{Effects of Seasonal Generation and Sex Dimorphism on Body Size}

Differences in growth rate depending on the time at which the animals iwere born have been shown for $M$. oeconomus by: W a sile wski (1956b); Karase eva et al. (1967); Schwarzet al. (1964).

The resulits obtained in this study fully confirm that individuals of the spring generation of both sexes have significantly greater body dimensions than individuals of the autumn generation (Table 7). In respect of skull dimensions, however, individuals of the spring generation have significantly greater $R B$ and $B c H$ in both sexes. In females two other dimensions are significantly greater $-Z y B$ and $M x T R L$. In the remaining skull measurements mean values are significantly higher in individuals of the autumn generation (Table 7).

The skulls of individuals of both generations thus differ from each other in respect of proportions. The spring generation is distinguished by short but wide skulls and a distinctly vaulted braincase, while the autumn generation has flat, longer and narrower skulls. These differences can be clearly seen in the correlation structure of the skull. In females during the spring period the number of measurements correlated with each other is smaller than in autumn, whereas in males the reverse is the case ( $\mathrm{M} \mathrm{a} \mathrm{k}$ ow s ki, in prep.).

Individuals of the spring generation of the root vole grow intensively and attain maximum dimensions within $4-5$ months, the growth rate of females being greater (Fig. 13). This is connected with their earlier 
attainment of sexual maturity in the case of females born in spring, as shown for this species by a large number of authors (Kratochvil \& Rosicky, 1955; Karaseeva et al., 1957; Snigirevskaja, 1961).

Individuals of the autumn generation, on the other hand, grow intensively for $1-2$ months, after which their growth rate slows down considerably (Fig. 13). In certain dimensions ( $\mathrm{BcH}$ and $\mathrm{Bwt}$ ) there is even a drop in mean values.

Analysis of age structure and reciprocal relationships between generations ( $\mathrm{Schw}$ a r z et al., 1969/70; Fe d y k, 1974a, b; G liwic z, 1975) shows that there is a specific alternation of generations in rodent populations. Fed yk (1974b) gave a general diagram of changes for C. glareolus, which fully corresponds to changes in the root vole populations: the spring reproduction base of the population consists of animals born at the end of the preceding reproduction season; it begins reproduction, producing numerous rapidly growing and maturing progeny (chiefly females) - the spring generation. Individuals of this generation interbreed and their slowly growing progeny forms the main part of the overwintering population.

It would therefore appear that it is a case of certain general regularities relating to voles, and possibly also to rodents as a whole. Anderson (1970) terms rodent species with this differentiation of seasonal generations - cyclomorphic. It is understandable that the different generations, on account of physiological, behavioural and genetic differentiation, play an important ecological and evolutional part in the continuance of populations of different species.

$\mathrm{Schwarz}$ (1962) and $\mathrm{Zejda}$ (1971) demonstrated the close connection existing between sexual maturation and animals' dimensions. Bojkova \& Bojkov (1971) after Pantaleyev \& Terehina (1976) found that in several species of rodents, including $M$. oeconomus, it is the heaviest and largest individuals, in respect of body length, which begin reproduction. The rapid jump in increase of body measurements in old adult males observed in $M$. oeconomus in spring is undoubtedly connected with their earlier maturation (Figs. 2, 3).

Confirmation of the close relations between sexual maturation and growth in rodents is supplied by the results on growth of seasonal generations. They show that sex dimorphism depends on the season and time at which the animals mature sexually during the first calendar year of life. In old adults dimorphic difference are constantly maintained, more distinct in spring, less distinct in summer.

It would appear that this is the cause of the discrepancies between

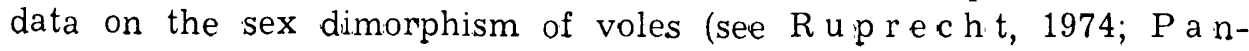


ta le yev \& Terehin a, 1976), or even the failure to find differences in dimensions of individuals of different sex (W a s ile w ski, 1956b; Gę bc z y ńska, 1964, 1967).

In the light of these data the supposition is confirmed that the data obtained on sex dimorphism in rodents depends on the number and quality of the samples examined.

\subsection{Cyclic Changes in the Population}

In addition to the differentiated growth rate of seasonal generations, there are also differences in the growth rate of body and skull in consecutive generations. As has already been shown, the largest individuals in almost all age classes occurred in 1966 and 1969, and percentage increases in dimensions were greatest at those times.

$\mathrm{Ch}$ i t t y (1952) showed that a characteristic feature of the population cycle is the attainment of the greatest body dimensions at a time of peak of numbers. Krebs \& Myers (1974) give three possible ways of relating changes in body size with numbers: (1) voles during the phase of peak and increasing numbers can live longer and attain maximum body dimensions at that time; (2) voles can grow more rapidly during the phase of increasing and peak numbers than during the phase of population reduction. This results in animals of uniform absolute age being larger during the phases of increasing and peak numbers; (3) the growth rate of young individuals (juv. and sub-ad.) may be identical in each year of the population cycle, but their maximum weight may differ for different phases of the cycle.

The data obtained so far do not reveal differences in the age of individuals in different phases of the population cycle ( $\mathrm{Ch}$ i t t y, 1952), or else individuals from the year of maximum numbers are on the average younger than individuals from the phase of population reduction ( $\mathrm{Krebs}, 1964 \mathrm{a})$. There are no significant differences in mean values of lens weight for age class $V$ in the study population of $M$. oeconomus in successive years, which indicates that the average age is the same (Table 10). Maximum mean lens weight (although not differing statistically from other means) in females during the phase of decrease in numbers in 1968 would thus confirm the observations made by $\mathrm{Krebs}$ (1964a).

The third possibility of interpreting these results is difficult to document, on account of the lack of a sufficient number of measurements available at all times ( $\mathrm{Krebs} \& \mathrm{Myers}$, 1974), and therefore differentiation in growth rate is held to play the most important part. $\mathrm{Krebs}$ et al. (1969) showed for Microtus pennsylvanicus and 
M. ochrogaster that their growth rate is greater during the phase of increasing and peak population numbers. A similar relation was found by $\mathrm{Krebs}$ (1966) in $M$. californicus, but this was effected by the season and reproduction. $\mathrm{K}$ a $\mathrm{r}$ a s e va et al. (1957) also state that growth in $M$. oeconomus was greater during the year of its maximum numbers. Considerable weights during years of peak numbers have also been found for other voles and for lemmings (cf. Krebs \& \& Myers, 1974).

$\mathrm{Zimmermann} \mathrm{(1955)} \mathrm{found} \mathrm{that} \mathrm{mandibular} \mathrm{length} \mathrm{in} M$. arvalis also varies during the population cycle in the same way as body weight. $\mathrm{Krebs}(1964 \mathrm{~b})$ found cyclic variation in body and skull measurements, and their dependence on density, for two species of lemming from northern Canada. F u lle r (1969), however, did not find variations in mean weight in fluctuating populations of $C$. rutilus and $C$. gapperi. $\mathrm{G}$ a in es \& R os e (1976) did not show any connection between size index and numbers in a cyclically varying population of $M$. ochrogaster.

In the case of the studied population of $M$. oeconomus there is difficulty in interpreting fluctuations in numbers due to the use of two different removal methods. On the basis of analysis of trappability indexes and calculated densities (Fig. 11) (B u chalc zyk \& P uce k, 1968) it may be concluded that: The fluctuation cycle lasts four years. Maximum numbers were found in 1966 and in 1970. The successive peak in numbers was not however observed in 1974 as there was general decline in population numbers in this area.

The maximum numbers of $M$. oeconomus in 1966 correspond with the maximum dimensions of individuals (high positive mean values of deviation $_{\mathrm{S}}$ from linear regression of body length and $C b L$ ) (Fig. 11), which during the phase of decrease become lower and reach lowest dimensions with lowest population numbers in 1968. Further on, however, there is divergence - individuals from the growth phase are larger than individuals from the phase of peak numbers in 1970. The insufficient amount of data from subsequent years makes it impossible carry out further comparisons. Thus in this case no close relation is found between variations in numbers and body measurements. The question then arises as to what degree intensive removals carried out by the Standard Minimum method could affect the voles' population cycle.

In the light of data from literature it would appear that they did not exert any important effect. Adamczyk \& Walkowa (1971) removed $32 \%$ of individuals from a Mus musculus population, but did not find reduction in numbers. Similarly $\mathrm{Krebs}$ (1966), removing all individuals of $M$. californicus weighing over $40 \mathrm{~g}$ from the population 
every two weeks (which sometimes constituted $50 \%$ of the animals caught), was unable to prevent increase in population numbers. The effect of the trapping area may be compared to the activities of unspecialized predators in this area. In general it is assumed (Fitzgerald, 1972; Stendell, 1972 after Krebs \& Myers, 1974) that predators are not able to prevent population growth, but may accelerate reduction in numbers and maintain its low state, which postipones the start of the next cycle.

While removals in 1966 could have no important effect on the numerical state of the population, $S M$ removals in followings years might have affected the social composition, degree of tendency to migrate and numbers in 1969. The absence of appropriate data, however, makes it impossible to give full consideration to the causes of the absence of synchronization in the population cycle and size of body measurements.

Acknowledgements: My warmest thanks are due to Professor Z. Pucek for his assistance and supervision during the course of this study. My gratitude is also due to him for making it possible for me to carry out a period of scientific research in the Mammals Research Institute PAS and for the material available for these studies. Thanks are also due to Dr. M. Gębczyński for hi's critical reading of this text and to all members of the Mammals Research Institute who gave me their assistance, particularly in preparing skulls. I should also like to express my gratitude to D. Szczerbak, M.Sc., of the Eódź University Computer Centre, for carrying out statistical calculations.

\section{REFERENCES}

1. A damczyk K. \& Wa lkowa W., 1971: Compensation of numbers and production in a Mus musculus population as a result partial removal. Ann. Zool. Fennici, 8: 145-153.

2. Anderson P. K., 1970: Ecological structure and gene flow in a small mammals. Symp. zool. Soc. Lond, 26: 299-325.

3. Askaner T. \& Hanss on L., 1967: The eye lens as age indicator in small rodents. Oikos, 18: 151-153.

4. Ba uer K., 1953: Zur Kenntnis von Microtús oeconomus mehelyi Ehik. Zool. Jb., 82, 1/2: 70-94.

5. Buchalczyk T., Gębczyńska Z. \& Pucek Z., 1970: Numbers of Microtus oeconomus and its noxiousness in forest plantation. EPPO Publ., ser. A, No 58: 95-99.

6. Buchalczyk T. \& Pucek Z., 1968: Estimation of the numbers of Microtus oeconomus using the Standard Minimum method. Acta theriol., 13: $461-482$.

7. Buchalczyk.T. \& Pucek Z., 1978: The succession of small mammals in a drained peat-lbog. II Congressus Theriol. Intern., Abstracts of Papers. p. 193. Brno.

8. Chitty D., 1952: Mortality among voles (Microtus agrestis) at Lake Vyrnvy, Montgomeryshire in 1936-39. Phil. Trans. R. Soc., ser. B, 236: 505-552.

9. Chitty H. \& Chitty D., 1962: Body weight in relation to population phase in Microtus agrestis. Symp. Theriologicum Brno, 1960: 77-86. 
10. Dehnel A., 1946: Przyczynek do znajomości przedstawicieli Microtus Schrank z Polesia i Wileńszczyzny. Fragm. Faun. Muz. Zool. Pol., 5: 1-24.

11. Dehnel A., 1949: Badania nad rodzajem Sorex L. Annls Univ. M. Curie-Sk ?odowska, C, 4: 17-97.

12. Ehik G., 1953: The occurrence of the root-vole (Microtus oeconomus (Pall.) at the Kisbalaton. Ann. Hist.-Natur. Mus. Nat., s. nova, 3: 521-526.

13. F a lconer D. S., 1964: Introduction to quantitative genetics. Oliver \& Boyd: $1-365$. London.

14. Fedyk A., 1974a: Gross body composition in postnatal development of thè bank vole. I. Growth under laboratory conditions. Acta theriol., 19: 381-401.

15. F edyk A., 1974b: Gross body composition in postnatal development of the bank vole. II. Differentiation of seasonal generations. Acta theriol., 19: 403-427.

16. Fulle r W. A., 1969: Changes in numbers of three species of small rodent near Great Slave Lake, N. W. T. Canada, 1964-1967, and their significance for general population theory. Ann. Zool. Fennici, 6: 113-144.

17. Gaines M. S. \& Rose R. K., 1976: Population dynamics of Microtus ochrogaster in eastern Kansas. Ecology, 57: 1145-1161.

18. Gębczyńska Z., 1964: Morphological changes occurring in laboratory Microtus agrestis with age. Acta theriol., 9: 67-79.

19. G ę b c z y ńsk a Z., 1967: Morphological variability of Lagurus lagurus (Pallas, 1773) in laboratory conditions. Acta theriol., 12: 535-543.

20. Gębczyńska Z., 1969: Nornik północny jako szkodnik upraw leśnych. Sylwan, 4: 57-60.

21. Gębczyńska Z., 1970: Bioenergetics of a root vole population. Acta theriol., 15: $33-65$.

22. Gębczyńska Z. \& Buchalczyk A., 1969: Norniki jako zwierzęta laboratoryjne. III. Nornik północny, Microtus oeconomus (Pallas, 1776). Zwierz. labor., 7: $37-60$.

23. Gębzyńska Z. \& Gębczyński M., 1971: Length and weight of the alimentary tract of the root vole. Acta theriol., 16: 359-369.

24. Gliwicz J., 1975: Age structure and dynamics numbers in an island population of bank voles. Acta theriol., 20: 57-69.

25. Gourley R. S. \& Jannett F. J., 1975: Pine and montane vole age estimates from eye lens weights. J. Wildl. Manage., 39: 550-556.

26. Guld H. N. \& Kreeger F. B., 1948: The skull of the Louisiana muskrat (Ondatra zibethica rivalicia Bangs): I The skull in advanced age. J. Mammal., 29: $138-148$.

27. Kanep S. V., 1967: Opyt biometričeskogo issledovanija priznakov 厄erepa nekotoryh blizkih vidov seryh polevok fauny SSSR. Acta theriol., 12: 111-134.

28. Karaseeva E. V., Narskaja E. V. \& Bernstein A. D., 1957: Polevka-ekonomka, obitajuščaja v okrestnostach ozera Nero Jaroslavskoj oblasti. Bjull. MOIP, 62: 5,-18.

29. Krata chvíl J. \& Rosicky B., 1955: Hraboš severni (Microtus oeconomus), relikt zviřeny $\mathrm{z}$ dobovy lodove $\mathrm{v}$ CSR. Prace Brnenske Zaklady CAV, 27: $33-72$.

30. Kratochvíl J. \& Mrazova J., 1976: Das Volumen des Cavum cranii bei Arvicola terrestris (Rodentia, Mammalia). Zool., listy, 25: 97-112.

31. Kratochvíl J., Bar uš V., Tenora F. \& Wiger R., 1977: The growth of the skull during postnatal development of Lemmus lemmus (Mammalia, Rodentia). Acta Sc. Nat., 11: $1-33$. 
32. Krebs C. J., 1964a: The lemming cycle at Baker Lake, Northwest Territories, during 1959 62. Arctic Inst. N. Amer. Tech. Paper, 15: 1-104.

33. K rebs C. J., 1964b: Cyclic variation in skull-body regression of lemmings. Can. J. Zool., 42: 631-643.

34. Krebs C. J., 1966: Demographic changes in fluctuating populations of Microtus californicus. Ecol. Monogr., 36: 239-273.

35. Krebs C. J., Keller B. L. \& Tamarin R. H., 1969: Microtus population biology: demographic changes in fluctuating populations of $M$. ochrogaster and $M$. pennsylvanicus in southern Indiana. Ecology, 50: 587-607.

36. Krebs C. J. \& M yers J. H., 1974: Population cycles in small mammals. Adv. Ecol. Res., 8: 267-399.

37. Krzysztofiak M. \& Urbanek D., 1975: Metody statystyczne. Państw. Wyd. Nauk.: $1-416$.

38. Martinet L., 1966: Determination de l'age chez le campagnol des champs (Microtus arvalis Pallas) par la pesee du crystallin. Mammalia, 30: 425-430.

39. M a y E E., 1974: Populacje, gatunki i ewolucja. Wiedza Powszechna: 1-592.

40. Morris P., 1972: A review of mammalian age determination methods. Mamm. $\operatorname{Rev}_{\text {, }}$ 2: 69-104.

41. Pantaleyev P. A. \& Terehina A. N., 1976: Issledovanije vnutripopuljacjonnoj izmenčivosti na primere vodjanoj polevki. Fauna i ekologija gruzunov, 13: 99-163.

42. Petrusewicz K., 1966: Dynamics, organisation and ecological structure of population. Ekol. Pol., A, 14: 413-436.

43. Pucek Z., 1963: Seasonal changes in the brain case of some representatives of the genus Sorex from Palearctic. J. Mammal., 44: 523 $\neg 536$.

44. Pucek Z., 1964: Część ogólna. [In: "Klucze do oznaczania kręgowców Polski. cz. V. Ssaki - Mammalia« Ed.: K. Kowalski]. Państw. Wyd. Nauk.: 1-280.

45. Pucek Z. \& Lowe V. P. W, 1975: Age criteria in small mammals. [In: „Small mammals: their productivity and population dydamics. F. B. Golley, K. Petrusewicz, L. Ryszkowski eds.]. Cambridge Univ. Press: 55-72. Cambridge.

46. Ruprecht A. L., 1974: Craniometric variations in central European populations of Ondatra zibethica (Linnaeus, 1776). Acta theriol., 19: 436-507.

47. S c hwarz S. S., 1962: MorfologiCeskije i ekologičeskije osobiennosti zemlerojek na krajnem severnom predele ich rasprastranienija. Tr. In-ta biol., Uralskogo Filiala AN SSSR, 29: 45-51.

48. S c hwarz S. S., 1969: Evolucjonnaja ekologija životnyh. AN SSSR Uralskogo Filiala: 1-198, Sverdlovak.

49. S chwarz S. S., Pokrovskij A. N., Istchenko V. G., Olenjev V. G., Ovtschinnikova N. A. \& Pjastolova O. A., 1964: Biological peculiarites of seasonal generations of rodents, ${ }^{-}$with special references to the problem of senescence in mammals. Acta theriol., 8: 11-41.

50. Schwarz S. S., Bolšakov V. N., Olenjev V. G., Ovtschinnikova N. A. \& Pjastolova O. A, 1969/70: Population dynamics of rodents from northern and mountains geographical zones. [In: "Energy flow trough small mammal populations«, K. Petrusewicz, L. Ryszkowski eds.]. Państw. Wyd. Nauk.: 187-201, Warszawa.

51. Snigirevskaja E. M., 1961: Nabludenja nad polewkoj-ekonomkoj na ostrovah sredniej Volgi. Tr. Zool. In-ta. AN SSSR, 29: 137-155.

52. Y a blok ov A. V., 1966: Izmenčivost mlekopitajuščih. Nauka: 1-362. Moskva. 53. Wasilewski. W., 1952: Badania nad morfologia Clethrionomys glareolus Schreb. Annls Univ. M. Curie-Skłodowska, C, 7: 119-211. 
54. Wa sile w ski W., 1956a: Untersuchungen über die morphologische Veränderlichkeit der Erdmaus (Microtus agrestis Linne). Annls Univ. M. Curie-Sklodowska, C, 9: 261-305.

55. Wasilewski W., 1956b: Untersuchungen über die Veränderlichkeit des Microtus oeconomus Pall. in Białowieża-Nationalpark. Annls Univ. M. Curie-Skłodowska, C, 9: 355-386.

56. Wasilewski W., 1960: Angaben zur Biologie und Morphologie der Kurzohrmaus, Pitymys subterraneus (de Selys Longchamps, 1835). Acta theriol., 4: $185-247$.

57. Zejda J., 1971: Differential growth of three cohorts of the bank vole, Clethrionomys glareolus Schreber, 1870. Zool. listy, 20: 229-245.

58. Zimmermann K., 1955: Körpergrösse und Bestandsichte bei Feldmaus (Microtus arvalis). Z. Säugertierkde, 20: 114-118.

Accepted, December 14, 1979.

Janusz MARKOWSKI

ZMIENNOSC MORFOMETRYCZNA POPULACJI NORNIKA POENOCNEGO

Streszczenie

Badaniami objęta została populacja nornika pólnocnego, Microtus oeconomus (Pallas, 1776), która znajdowała się pod silnym wplywem zmieniających się czynników środowiskowych wywolanych melioracją i wprowadzeniem na części obszaru upraw leśnych. Widocznym efektem tego oddziaływania bylo stałe zmniejszanie liczebne populacji wyrażone wskaźnikiem lowności (Ryc. 11). W trakcie badań w latach 1966-1974 odłowiono 4416 osobników, z których do analizy biometrycznej wybrano 2424 (Tabela 1). W oparciu o analizę podstawowych wymiarów ciała i czaszki prześledzono zmienność $w$ aspekcie różnic dymorficznych, generacji sezonowych i zmian liczebności populacji. Wykorzystując ciężar suchej masy soczewek, dlugość $\mathrm{Cb}$. oraz rozwój grzebieni kostnych czaszki wydzielono 5 klas wiekowych, których biometryczne charakterystyki przedstawiono $w$ Tabeli 10.

Dymorfizm plciowy wyraźniej uwidacznia się u przezimków (V klasa wiekowa), średnie wymiary ciała i czaszki samców są istotnie statystycznie większe (Tabela 2, 6). Natomiast dymorfizm pliciowy $u$ zwierząt $w$ pierwszym roku życia ma charakter zmian sezonowych. Samice generacji wiosennej szybciej dojrzewają płciowo, cechują się szybszym wzrostem i osiągają większe rozmiary aniżeli samce tej samej generacji. W generacji jesiennej większymi rozmiarami cechują się samce (Ryc. 2, 3, 13; Tabela 7).

Istnieje wyraźne zróżnicowanie tempa wzrostu między osobnikami generacji wiosennej i jesiennej. Szczególnie silnie uwidacznia się to we wzroście parametrów ciała (długości i ciężaru) i Cb (Ryc. 13), istniejące różnice są statystycznie istotne $(P<0.05)$ (Tabela 7). Srednie wartości wysokości puszki mózgowej norników 
obniżają się jesienią (Ryc. 9, 10). Obniżenie wysokości puszki mózgowej obserwuje się w miarę starzenia zwierząt (wg klas ciężaru soczewek) (Tabela 8). Sugerowałoby to, że nie jest to efektem zimowej depresji czaszki (zjawisko Dehnela) lecz zróżnicowania tempa wzrostu dlugości podstawy czaszki i wysokości puszki mózgowej.

Istnieją statystycznie istotne różnice między średnimi wymiarami ciała i czaszki w kolejnych latach, przy czym jednocześnie istnieje tendencja spadku tych wymiarów oraz zmniejszanie ich zakresów (Ryc. 6a, b; 7b; 8b, c; Tabela 5). Tendencja okazała się istotna statystycznie jedynie $w$ przypadku długości i ciężaru ciala (Tabela 9). Zaobserwowane zmiany średnich wymiarów ciała nie są ściśle skorelowane ze zmianami liczebności (Ryc. 11). 